Marco Antonio Leon-Roman

Redução microbiológica intracanal com laser em baixa intensidade associado a fotossensibilizante - estudo in vivo em dentes de cães

SÃO PAULO

2008 
Marco Antonio Leon-Roman

\section{Redução microbiológica intracanal com laser em baixa intensidade associado a fotossensibilizante - estudo in vivo em dentes de cães}

Tese apresentada ao Programa de PósGraduação em Clínica Cirúrgica Veterinária da Faculdade de Medicina Veterinária e Zootecnia da Universidade de São Paulo para obtenção do título de Doutor em Medicina Veterinária

Departamento:

Cirurgia

Área de concentração:

Clínica Cirúrgica Veterinária

Orientador:

Prof. Dr. Marco Antonio Gioso

SÃO PAULO

2008 
Autorizo a reprodução parcial ou total desta obra, para fins acadêmicos, desde que citada a fonte.

DADOS INTERNACIONAIS DE CATALOGAÇÃO-NA-PUBLICAÇÃO

(Biblioteca Virginie Buff D’Ápice da Faculdade de Medicina Veterinária e Zootecnia da Universidade de São Paulo)

Leon-Roman, Marco Antonio

Redução microbiológica intracanal com laser em baixa intensidade associado ao fotossensibilizante - estudo in vivo / Marco Antonio LeonRoman. - São Paulo : M. A. Leon-Roman, 2008.

$90 \mathrm{f}$ : : il.

Tese (doutorado) - Universidade de São Paulo. Faculdade de Medicina Veterinária e Zootecnia. Departamento de Cirurgia.

Programa de Pós-Graduação: Clínica Cirúrgica Veterinária.

Área de concentração: Clínica Cirúrgica Veterinária.

Orientador: Prof. Dr. Marco Antônio Gioso.

1. Terapia fotodinâmica. 2. Laser. 3. Tratamento de canal. 4. Avaliação microbiológica. I. Título. 


\begin{tabular}{|c|c|c|c|c|}
\hline \multicolumn{5}{|c|}{ ERRATA } \\
\hline Página & Parágrafo & Linha & Onde se lê & Leia-se \\
\hline $\begin{array}{l}\text { Ficha } \\
\text { satalográfica }\end{array}$ & 2 & 2 & - estudo in vivo & - estudo in vivo em dentes de cães \\
\hline 10 & 1 & 2 & em cães - in vivo & $\begin{array}{c}\text { Fotosensibilizante - estudo in vivo em dentes de } \\
\text { cães }\end{array}$ \\
\hline 10 & 1 & 4 & $89 f$. & $90 \mathrm{f}$. \\
\hline 11 & 1 & 4 & $89 \mathrm{f}$. & $90 \mathrm{f}$. \\
\hline
\end{tabular}




\section{HOSPITAL VETERINÁRIO}

Ao llmo. Sr.

Prof. Dr. Marco Antonio Gioso

\section{DECLARAÇÃO}

Declaramos que o projeto "Redução bacteriana intracanal com laser em baixa intensidade - Estudo in vivo e aplicação na rotina dos casos atendidos no Hospital Veterinário da FMVZ/USP", sob a sua responsabilidade, previamente aprovado pela Comissão de Bioética dessa Faculdade, foi analisado e atende as normas da Comissão de Ética desse Hospital, que acompanhará administrativamente sua execução. Substituição do responsável, inserção de novos colaboradores e mudanças na metodologia proposta deverão ser imediatamente comunicados a essa comissão, assim como as datas de suspensão ou término do projeto.

São Paulo, 07 de maio de 2008.

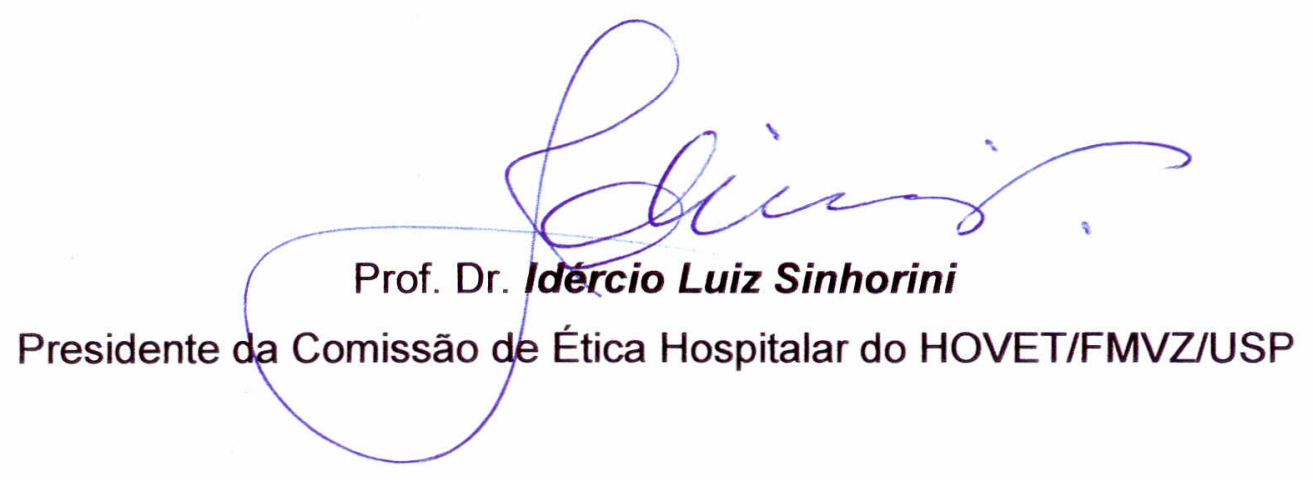




\section{FOLHA DE AVALIAÇÃO}

Nome: LEON-ROMAN, Marco Antonio

Título: Redução microbiológica intracanal com laser em baixa intensidade associado a fotossensibilizante - estudo in vivo em dentes de cães

Tese apresentada ao Programa de PósGraduação em Clínica Cirúrgica Veterinária da Faculdade de Medicina Veterinária e Zootecnia da Universidade de São Paulo para obtenção do título de Doutor em Medicina Veterinária

Data:

1

Banca Examinadora

Prof.Dr.: Instituição:

Assinatura: Julgamento:

Prof.Dr.: Instituição:

Assinatura: Julgamento:

Prof.Dr.: Instituição:

Assinatura: Julgamento:

Prof.Dr.: Instituição:

Assinatura: Julgamento:

Prof.Dr.: Instituição:

Assinatura: Julgamento: 


\section{DEDICATÓRIA}

Aos meus queridos pais, Walter e Antonieta, por todo amor e carinho dedicados por toda uma vida inteira. Deles, aprendi que a melhor herança que um filho pode receber não são posses ou fortunas, mas sim a educação. 


\section{DEDICATÓRIA}

Ao LOC, não como laboratório ou equipe, mas como um "alguém" que vi nascer e crescer, e que foi fundamental na minha formação e desenvolvimento profissional. O carinho que tive por este laboratório estará guardado para sempre. 


\section{AGRADECIMENTOS}

À FAPESP, por financiar a pesquisa e conceder as bolsas de mestrado e doutorado, assim como as de iniciação científica.

Ao Prof.Dr.Marco Antonio Gioso, pela oportunidade dada em $1998 \mathrm{com}$ a primeira bolsa na FMVZ/USP e o convite para ser seu primeiro orientado em 1999, na área de odontoveterinária, quando o LOC ainda nem existia. Agradeço por todas as oportunidades destes dez anos de convivência, e por sempre ter sido um exemplo de ética e profissionalismo.

Ao técnico de laboratório José Miron Oliveira da Silva, por todos os anos de trabalho juntos no LOC, desde sua criação em 2000.

Aos pré-históricos amigos locmaniacos Alexandre Venceslau e João Rossi Jr., companheiros desde as primeiras prestações de contas acompanhadas de pizza, dos passeios na "conquista do mundo", ainda no século passado... e pela sinceridade que me brindam até hoje.

Aos locmaniacos, Juliana Kowalesky, Fernanda Lopes, Fernanda Hofmann, Mariana Lage Marques, Jonathan Ferreira, Vanessa Carvalho, Fabiana Cunha e Flávia Ribeiro pela honra de permitirem que eu pudesse participar de seus aprendizados, e pelo orgulho de, hoje, aprender muito com todos eles.

Agradecimento especial às amigas locmaniacas Cláudia Emilio, pela contribuição científica ao desenvolvimento da tese, Cristina Albuquerque, pelas correções e formatações da tese, e Fernanda Vituri, pelas aulas de flash e ajudas na montagem da apresentação da defesa.

Aos bolsistas Marcelo Kitsis e Izabella Ducatti, por sua fundamental participação no desenvolvimento deste experimento. 


\section{AGRADECIMENTOS}

A todos os médicos veterinários e residentes do HOVET, pelos oito anos de convívio profissional, permitindo que o LOC não fosse somente um laboratório de pesquisa, mas também de alguma forma, prestador de serviço à comunidade.

Agradecimento especial às médicas veterinárias do HOVET, Denise Simões, Bruna, Vera, Audrey, Khadine, Sandra, Viviane e Patrícia, por permitirem participar de suas rotinas, alavancando a casuística do LOC.

Aos anestesistas do HOVET, João e Rodrigo, pela contribuição anestésica nos procedimentos cirúrgicos do experimento. Em especial, ao Dr.Rafael, ex-anestesista do HOVET, que teve muita paciência durante meu aprendizado odontológico.

Aos funcionários Jesus, Otávio, Lelis, Carlito, Toninho, Milton, que assim como os médicos veterinários do HOVET, sempre permitiram que o atendimento da casuística do LOC se desenvolvesse de forma eficiente, e com isso, engrandecendo o aprendizado.

À cirurgiã-dentista Patricia Ferrari, pela orientação do projeto, referente à análise microbiológica no ICB-USP. E o cirurgião-dentista Ricardo Hayek, cuja pesquisa foi inspiradora deste trabalho, e pela orientação do projeto, referente à terapia fotodinâmica.

Ao amigo e professor Ricardo Dias, do Departamento de Epidemiologia (VPS), por colocar à nossa disposição sua boa vontade ao realizar a avaliação estatística deste experimento.

Aos pesquisadores, Nikos Soukos (EUA) e Ake Möller (Suécia) pela gentiliza em contribuir, por email e arquivos enviados, enriquecendo a literatura deste trabalho.

Aos secretários do departamento de Cirurgia, Alessandra e Ney, e as secretária do HOVET, Janilda, pela grande colaboração e orientação durante o desenvolver da burocracia.

À bibliotecária Elza, pela orientação para que este trabalho fosse terminado de maneira elegante e impecável, mesmo na corrida contra o relógio. 


\section{RESUMO}

LEON-ROMAN, M. A. Redução microbiologica intracanal com laser em baixa intensidade associado a fotosensibilizante em cães - estudo in vivo em dentes de cães. [Intracanal microbiological reduction using low intensity laser and photosensitizer associated- in vivo study in teeth of dogs]. 2008. $89 \mathrm{f}$. Tese (Doutorado em Medicina Veterinária) - Faculdade de Medicina Veterinária e Zootecnia, Universidade de São Paulo, São Paulo, 2008.

Foi avaliada a eficácia da terapia fotodinâmica, empregando o fotossensibilizante azuleno e laser de baixa intensidade, associado ao preparo químico-cirúrgico convencional (hipoclorito de sódio a 0,5\% e endo-ptc) de canais radiculares de dentes de cães. Para isso, foram utilizados 20 cães provenientes do Hospital Veterinário da FMVZ/USP, cada qual apresentando um dente unirradicular com morte e contaminação pulpar e, radiograficamente, lesão de rearefação óssea periapical. Os cães foram divididos em dois grupos de dez animais. O primeiro grupo foi submetido ao tratamento endodôntico, iniciando a anti-sepsia através do preparo químico-cirúrgico e, posteriormente a terapia fotodinâmica. O segundo grupo foi submetido ao tratamento endodôntico, iniciando a anti-sepsia pela terapia fotodinâmica e, posteriormente foi realizado o preparo químico-cirúrgico. Os resultados mostraram que a terapia fotodinâmica intracanal tem eficácia semelhante à anti-sepsia do preparo químico-cirúrgico. A ordem de emprego do preparo químico-cirúrgico e terapia fotodinâmica não influencia no resultado de anti-sepsia. O emprego de azuleno irradiado por laser de baixa potência tem grande eficácia sobre espécies de enterococos no interior dos condutos, e é eficaz na diminuição do número de bactérias totais intraradiculares. Os resultados sugerem que há uma tendência em afirmar que o emprego de azuleno irradiado por laser possa diminuir a quantidade de espécies de leveduras.

Palavras-chave: Terapia fotodinâmica. Laser. Tratamento de canal. Avaliação microbiológica 


\begin{abstract}
LEON-ROMAN, M.A. Intracanal microbiological reduction using low intensity laser and photosensitizer associated - in vivo study in teeth of dogs [Redução microbiológica intracanal com laser em baixa intensidade associado a fotosensibilizante - estudo in vivo em dentes de cães]. 2008. 89 f. Tese (Doutorado em Medicina Veterinária) - Faculdade de Medicina Veterinária e Zootecnia, Universidade de São Paulo, São Paulo, 2008.
\end{abstract}

The photodynamic therapy efficacy was evaluated, using the photosensitizer azulene and low intensity laser, associated to the conventional root canal therapy $(0,5 \%$ sodium hipoclorite and endo-ptc endodontic paste) in teeth of dogs. Twenty dogs from the Veterinary Hospital of the FMVZ/USP were used, each one presenting one uniradicular tooth with death and pulp contamination and, radiographic injury of periapical bone reabsorption. These dogs were divided in two groups of ten animals. The first group was submitted to the endodontic treatment, starting the anti-sepsis through the conventional root canal therapy and, subsequently the photodynamic therapy. The second group was submitted to the endodontic treatment, starting the anti-sepsis by photodynamic therapy and, subsequently the conventional root canal therapy. The results showed that intracanal photodynamic therapy has similar efficacy compared to the anti-sepsis of the conventional root canal therapy. The order of application of the conventional root canal therapy and photodynamic therapy does not interfere in the result of anti-sepsis. The use of irradiated azulene by low intensity laser has strong efficacy over species of enterococus inside the ducts. The use of irradiated azulene by low intensity laser is efficient in the reduction of total numbers of intracanal bacterias. The results suggest that there is a tendency to affirm that the use of irradiated azulene by low intensity laser can reduce the quantity of species of yeast.

Key words: Photodynamic therapy. Laser. Root canal therapy. 


\section{LISTA DE FIGURAS}

FIGURA 1- CANINO INFERIOR DIREITO, APRESENTANDO FRATURA DA COROA COM EXPOSIÇÃO DO CANAL RADICULAR, LEVE ESCURECIMENTO DENTÁRIO E CONTEÚDO MORTIFICADO NO INTERIOR DO CONDUTO

FIGURA 2- RADIOGRAFIA INTRA-ORAL DE DENTE CANINO SUPERIOR ESQUERDO, ONDE O HALO DE RADIOLUSCÊNCIA (EM DESTAQUE) SUGERE ÁREA DE RAREFAÇÃO ÓSSEA PERIAPICAL, COMPATÍVEL COM LESÃO ENDODÔNTICA SEGUIDA DE MORTE E CONTAMINAÇÃO PULPAR.

FIgURA 3 - EQUIPAMENTO LASER UTILIZADO NO EXPERIMENTO, MODELO KO650 (KROMAN, SÃo PAULO, BRASIL), ACOMPANHADO DA PONTEIRA ACOPLADA À PEÇA-DE-MÃO, ALÉM DO ÓCULOS DE PROTEÇÃO, DE USO OBRIGATÓRIO DURANTE A IRRADIAÇÃO DA LUZ LASER

FIgURA 4 - ASPECTO DA FIBRA-ÓPTICA, ACOPLADA À PONTEIRA DE APLICAÇÃO, desenvolvido pela empresa Kroman (SÃo Paulo, Brasil) ESPECIALMENTE PARA O USO EM CANAIS RADICULARES DE CÃES, DEVIDO À SUA GRANDE EXTENSÃO, QUANDO COMPARADO AO DENTE HUMANO

Figura 5 - APLICAÇÃO dO PROTOCOLO PROPOSTO POR MÖLlER (1966) PARA ANTISEPSIA DA SUPERFÍCIE DENTÁRIA. AMBAS AS SUBSTÂNCIAS FORAM APLICADAS COM EMPREGO DE ALGODÃO E PINÇA CLÍNICA ESTÉREIS E DIQUE DE BORRACHA, PARA COMPLETO ISOLAMENTO DO ELEMENTO DENTÁRIO .50

FIGURA 6 - APLICAÇÃO DO CORANTE AZULENO, COM EMPREGO DE SERINGA E AGULHA HIPODÉRMICA, NO INTERIOR DO CANAL RADICULAR DE UM DENTE CANINO INFERIOR DIREITO DE CÃO

FIGURA 7 - EMPREGO DE FIBRA-ÓPTICA NO INTERIOR DO CANAL RADICULAR DE DENTE CANINO INFERIOR DIREITO DE UM CÃO, PARA COMPLETA ENTREGA DA LUZ LASER EM TODA A EXTENSÃO DO CONDUTO, A FIM DE ATIVAR O CORANTE AZULENO PRESENTE NESTE ESPAÇO

FiguRA 8 - COLETA MICROBIOLÓGICA REALIZADA COM EMPREGO DE CONE-DE-PAPEL ESTÉRIL, INTRODUZIDO COM AUXÍLIO DE UMA PINÇA CLÍNICA ODONTOLÓGICA, NO INTERIOR DO CANAL RADICULAR DE DENTE CANINO INFERIOR DIREITO DE CÃO 
FIGURA 9 - ESQUEMA REPRESENTANDO OS TRÊS MOMENTOS DA COLETA MICROBIOLÓGICA COM EMPREGO DE CONES-DE-PAPEL ESTÉRIL, NOS DOIS GRUPOS ESTUDADOS, QUE DIFERIAM NO PROTOCOLO DE ANTI-SEPSIA QUANTO AO MOMENTO DE APLICAÇÃO DO PQC E PDT

FIGURA 10- ESQUEMA DE ISOLAMENTO DOS MICROORGANISMOS A PARTIR DO MEIO DE TRANSPORTE VGMA III, CONTENDO OS CONES-DE-PAPEL UTILIZADOS DURANTE A COLETA INTRACANAL, EM TRÊS MEIOS DE CULTURA (EM DIFERENTES DILUIÇÕES) PARA DETERMINAÇÃO DE UFC PARA BACTÉRIAS TOtAIS, ESPÉCIES dE ENTEROCOCOS E ESPÉCIES DE LEVEDURAS. CADA PLACA FOI SEMEADA EM TRIPLICATA, EM SEGUIDA, INCUBADA EM TEMPO E TEMPERATURA ESPECÍFICA. 


\section{LISTA DE TABELAS}

TABELA 1 - NúMERO DE DENTES do gRUPO I QUE APRESENTARAM ALGUM TIPO DE MICROORGANISMO NAS TRÊS ETAPAS DE AVALIAÇÃO MICROBIOLÓGICA, ANTES DA ANTI-SEPSIA, APÓS O PREPARO QUÍMICO-CIRÚRGICO E APÓS A TERAPIA FOTODINÂMICA

TABELA 2 - NúMERO DE DENTES dO GRUPO II QUE APRESENTARAM ALGUM TIPO DE MICROORGANISMO NAS TRÊS ETAPAS DE AVALIAÇÃO MICROBIOLÓGICA, ANTES DA ANTI-SEPSIA, APÓS O PREPARO QUÍMICO-CIRÚRGICO E APÓS A TERAPIA FOTODINÂMICA

TABELA 3 - CoMpaRAÇÃo dos títulos ENTRE AS COLETAS, ESTRATIFICADA PELOS PROTOCOLOS E MEIOS DE CULTURA

TABELA 4 - COMPARAÇÃO DOS TÍTULOS ENTRE OS PROTOCOLOS, ESTRATIFICADA PELOS MEIOS DE CULTURA E COLETAS 


\section{LISTAS DE ABREVIATURAS E SIGLAS}

\begin{tabular}{|c|c|}
\hline UFC & Unidade formadora de colônias \\
\hline GaAlAs & Gálio-Alumínio-Arsênio \\
\hline $\mathrm{NaOCl}$ & Hipoclorito de sódio \\
\hline HILT & $\begin{array}{l}\text { High intensity laser therapy (Terapia com laser de alta } \\
\text { intensidade) }\end{array}$ \\
\hline LILT & $\begin{array}{l}\text { Low intensity laser therapy (terapia com laser de baixa } \\
\text { intensidade) }\end{array}$ \\
\hline $\mathrm{He}-\mathrm{Ne}$ & Hélio-neônio \\
\hline FLL & Fotossensibilização letal \\
\hline ATP & Adenosina trifosfato \\
\hline $\mathrm{P}$ & Potência \\
\hline$E$ & Energia \\
\hline $\mathrm{J}$ & Joules \\
\hline VGMA III & Viability médium Goteborg anaerobically \\
\hline$P Q C$ & Preparo químico-cirúrgico \\
\hline PDT & Photodynamic therapy (terapia fotodinâmica) \\
\hline Er:YAG & Granada de ítrio-alumínio dopada com érbio \\
\hline Er,Cr:YSGG & Granada de ítrio-escândio-gálio dopada com érbio e cromo \\
\hline Nd:YAG & Granada de ítrio-alumínio dopada com neodímio \\
\hline O-toluidina & Orto-toluidina \\
\hline Bru & Ágar Brucella \\
\hline m-Ent & Ágar Enterococcus \\
\hline Sab & Ágar Sabouraud-dextrose \\
\hline
\end{tabular}




$\begin{array}{ll}\mathrm{OH}^{-} & \text {Radical hidroxila } \\ \mathrm{O}_{2}^{-} & \text {Peróxido de hidrogênio superóxido } \\ \mathrm{Na}^{+} & \text {Íon de sódio } \\ \mathrm{K}+ & \text { Íon de potássio } \\ \text { Tyr / Met/ His } & \text { Tirosinase / Metionina / Histidina }\end{array}$




\section{LISTAS DE SÍMBOLOS}

$\begin{array}{ll}\lambda & \text { Comprimento de onda } \\ { }^{\circ} \mathrm{C} & \text { Graus Celsius } \\ \mathrm{nm} & \text { Nanômetro } \\ \mathrm{mW} & \text { Miliwatts } \\ \mathrm{mg} & \text { Miligrama } \\ \mu \mathrm{g} & \text { Micrograma } \\ \mathrm{ml} & \text { Mililitros } \\ \% & \text { Porcentagem } \\ < & \text { Menor } \\ > & \text { Maior } \\ = & \text { Igual } \\ + & \text { Mais } \\ \mathrm{cm}^{2} & \text { Centímetro quadrado }\end{array}$




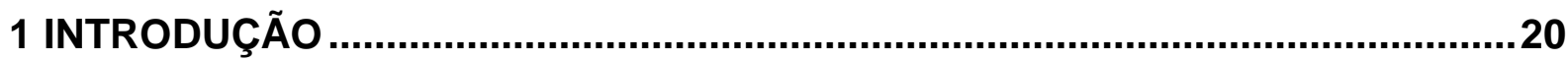

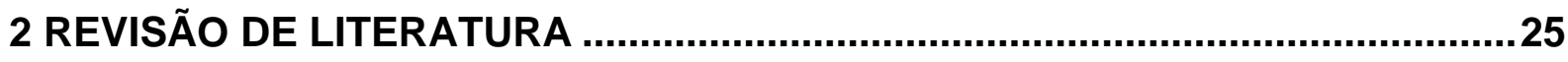

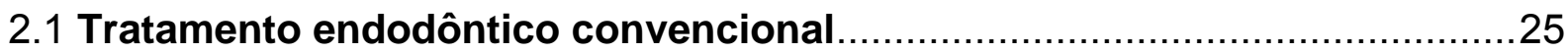

2.2 Aspectos microbiológicos dos canais radiculares contaminados ..............27

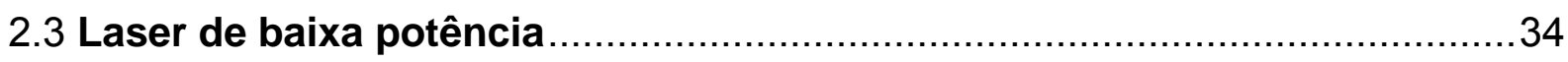

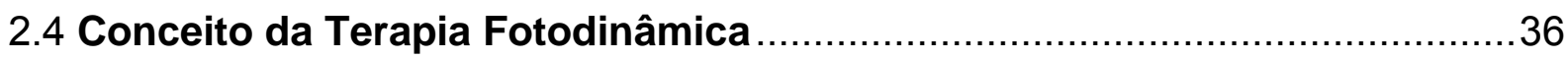

2.5 Ação da terapia fotodinâmica em microorganismos ...................................37

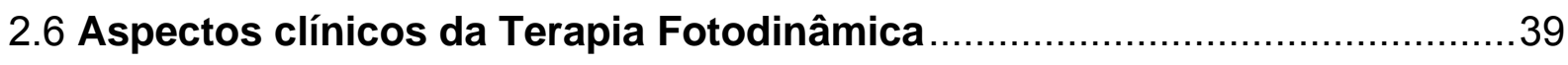

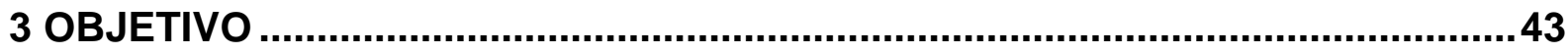

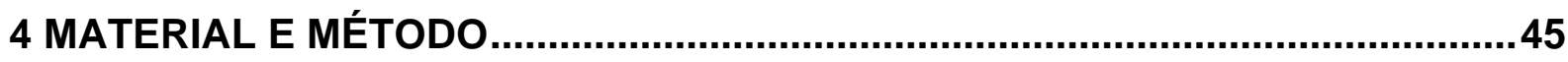

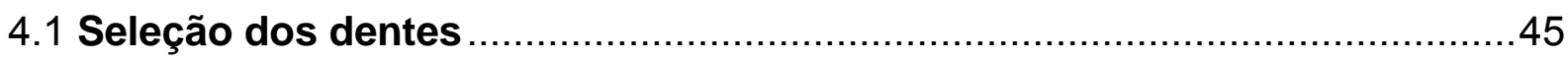

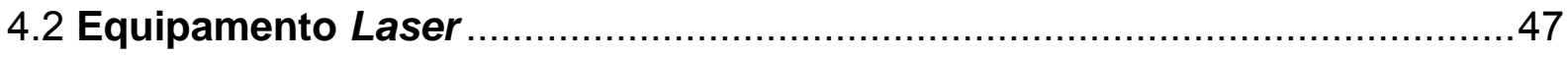

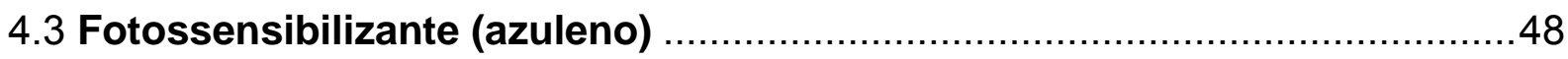

4.4 Técnica Operatória e Coleta Microbiológica ...............................................49

4.4.1 Avaliação da microbiota do canal radicular contaminado ................................50

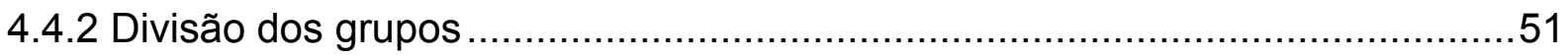

4.4.2.1 Grupo I (preparo químico-cirúrgico convencional antes da terapia fotodinâmica)......

4.4.2.2 Grupo II (terapia fotodinâmica antes do preparo químico-cirúrgico

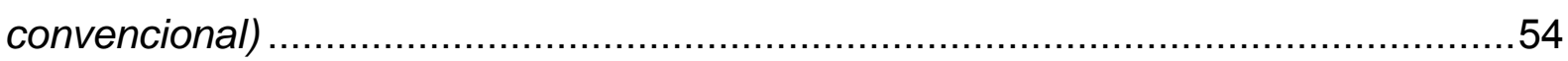

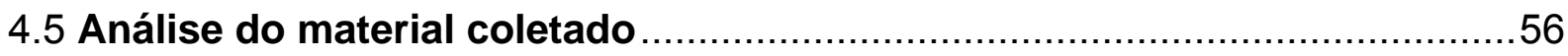

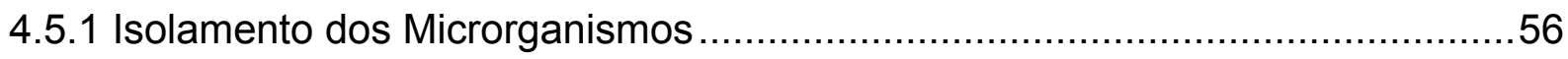




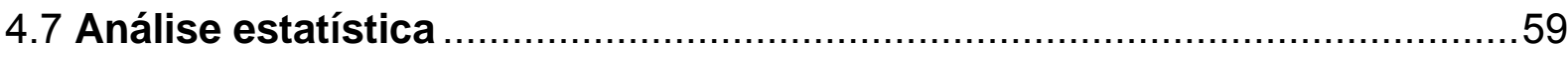

5 RESULTADOS............................................................................................... 61

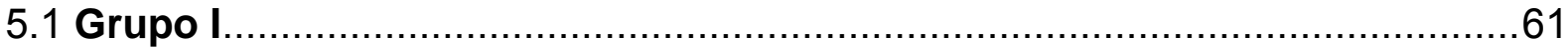

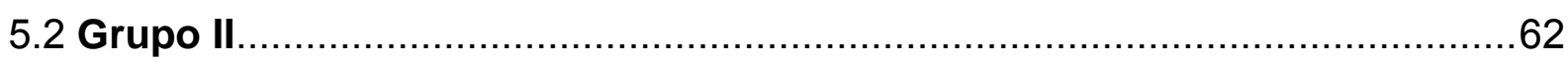

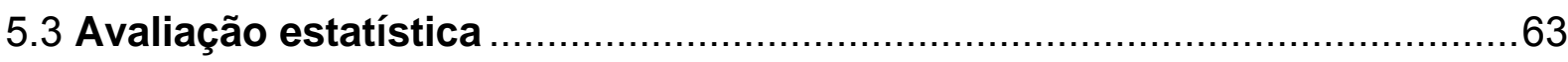

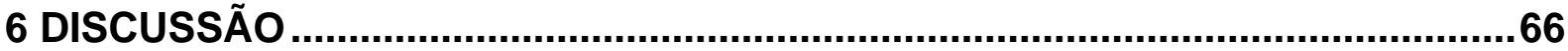

7 CONCLUSÕES ........................................................................................... 72

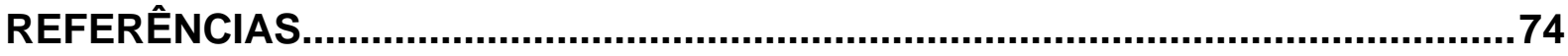

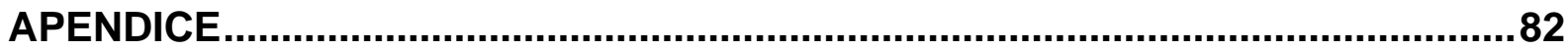


$I$ 


\section{INTRODUÇÃO}

A medicina veterinária vem acompanhando o desenvolvimento tecnológico ocorrido durante às últimas décadas, aprofundando o estudo de grande número de enfermidades, incluindo as orais. O estudo específico das doenças orais, tanto diagnóstico como tratamento, faz parte da área denominada "odontologia veterinária".

Há alguns anos, a odontologia veterinária era resumida apenas em "limpeza de dentes", quando era realizada a raspagem dentária simples. Hoje em dia, o médico veterinário brasileiro tem acesso à literatura internacional, e graças aos pioneiros da odontologia veterinária, este conhecimento tem sido difundido com grande velocidade.

Dentre todas as áreas da odontologia veterinária, destaca-se a endodontia, que é definida como ramo da odontologia que estuda a forma, função, fisiopatologia e terapia das afecções da polpa dentária quando sua vitalidade está comprometida ou destruída, e a extensão da lesão ao tecido periapical. O tratamento endodôntico é indicado sempre que as estruturas internas do dente são afetadas, como nos casos de exposição da polpa, pulpite e necrose pulpar, com a finalidade de manter a saúde do tecido pulpar, ou parte dele, revertendo a injúria dos tecidos periapicais.

Venceslau e Gioso (2000) examinaram a cavidade oral de 300 animais (cães e gatos), anestesiados para procedimento cirúrgico, excetuando o odontológico, no Hospital Veterinário da Faculdade de Medicina Veterinária e Zootecnia da Universidade de São Paulo. Dos 251 cães examinados, 24,30\% (61) apresentaram fratura dental com ou sem exposição da polpa, sendo os machos mais acometidos do que as fêmeas. Destes 61 animais, 37,70\% apresentaram exposição pulpar. Os dentes que mais fraturaram, independentemente de exposição do canal pulpar ou não, foram os quarto pré-molares superiores (15,63\%), seguidos dos caninos inferiores $(11,72 \%)$, acompanhados pelos caninos superiores com $10,94 \%$.

Uma variedade de termos é utilizada para descrever os tratamentos endodônticos na literatura humana e veterinária. O Tratamento de Canal 
Convencional ou Não-Cirúrgico refere-se a completa remoção do conteúdo do canal pulpar através de acesso coronal. A remoção da polpa viva é denominada "Pulpectomia Total", e o termo "Necropulpectomia" tem sido recentemente introduzido para diferenciar o esvaziamento do canal radicular quando a polpa estiver mortificada. A "Cirurgia Paraendodôntica" consiste no acesso cirúrgico do ápice, seguido de amputação do mesmo (apicectomia) e preenchimento do canal realizado por via retrógrada (retro-obturação), além da restauração.

A tecnologia laser apresenta-se, atualmente, como alternativa para tratamento tanto na Medicina como na Odontologia Humana. Diversos experimentos buscam inserir esta tecnologia na prática clínica, com objetivo de aprimorar as técnicas convencionais, e não de substituí-las. Dentro da endodontia, as propriedades dos lasers em vaporizar o tecido pulpar ou restos pulpares favorecem maior limpeza das paredes dentinárias, alteram a permeabilidade dentinária e promovem a anti-sepsia do canal radicular. Estudos mostram que a redução bacteriana, na maioria dos casos, ultrapassa os 99\% (GUTKNECHT et al., 1996).

O laser, de origem na língua inglesa, é um acrônimo para "Light Amplification by Stimulated Emission of Radiation" (Amplificação da Luz por Emissão Estimulada de Radiação). A radiação laser no intervalo de 300 a $600 \mathrm{~nm}$ é eletromagnética nãoionizante, apresenta um único comprimento de onda (monocromática), possui coerência espacial e temporal (propaga-se na mesma fase no espaço e no tempo) e pode apresentar uma alta densidade de energia em pequenos pontos devido a sua alta direcionalidade. Tais características conferem ao laser suas propriedades terapêuticas (WETTER, 2004).

Os lasers de baixa intensidade têm sido utilizados associados a fotossensibilizantes. Tal terapia, emitindo baixas intensidades, é responsável pelos efeitos não-térmicos, entre eles, os fotofísicos, fotoquímicos e fotobiológicos, não permitindo que a temperatura do tecido tratado ultrapasse $37{ }^{\circ} \mathrm{C}$. A terapia fotodinâmica já é utilizada no tratamento do câncer, por sua capacidade de destruição seletiva de tumores (BAUER et al., 2001; TOMASELLI et al., 2001). 
No início do século XX, Raab (1900 apud BAUGH; CLARK, 1959, p. 917) foi um dos primeiros pesquisadores a relatar os efeitos da terapia fotodinâmica quando notou que paramécios (protozoário causador da malária) morriam diante da exposição do corante acridina sob luz. Este pesquisador sugeriu que o efeito fosse causado pela transferência de energia da luz para a substância química, da mesma forma que a clorofila absorve luz, nas plantas.

A partir dessa observação, vários outros exemplos de fotossensibilizadores foram testados in vitro e in vivo. Algum tempo depois, a pesquisa tinha como principal objetivo o combate ao câncer através do desenvolvimento de novos fotossensibilizadores, assim como novas fontes de luz (MÜLLER et al., 1998).

Ackroyd et al. (2001) relatam que as primeiras fontes de luz foram as lâmpadas convencionais, não coerentes e policromáticas, com forte componente térmico associado. Então, surgiu o laser como opção mais eficiente para o emprego na terapia fotodinâmica. O laser produz luz monocromática de comprimento de luz conhecido, tornando-o seletivo aos corantes. Desta forma, a dose de radiação, assim como a área de radiação, pode ser bem calculada, focalizando o tratamento. Para a aplicação do laser nesta terapia, a opção de transmissão é a fibra óptica adaptada para acessar a lesão, através de microlentes e difusores.

Ao longo dos anos, diversos agentes fotossensibilizadores têm sido pesquisados. Experimentos têm concentrado sua atenção nas porfiridinas, corantes com estrutura química heterocíclica similar à clorofila e à hemoglobina. Seu mecanismo de ação, sob ativação pela luz, é de transferir energia ao oxigênio e outras moléculas, resultando na liberação de substâncias energéticas, de meia-vida curta e altamente reativas, interagindo com os sistemas biológicos, nocivos aos tecidos. Outros corantes foram testados para eliminação de microrganismos pela terapia fotodinâmica, como os corantes azuis, marrons, verdes, roxos, etc, complementares aos comprimentos de onda apresentados pelos lasers (KAWAMOTO, 2000).

Devido à sua eficiência comprovada em diversas pesquisas, a terapia fotodinâmica provou ser um excelente auxiliar no combate a infecções causadas por

${ }^{1}$ RAAB, O. Uber die wirkung fluoreszierender stoffe auf infusoria. Zeitschrift fur Biologie, v. 39, p. 524-546, 1900. 
microorganismos. Ainda mais, na cavidade oral, sua eficiência, baixo custo, ausência de efeitos sistêmicos e de aumento de resistência microbiana a drogas, indica esta terapia como importante auxiliar às terapias convencionais.

$\mathrm{Na}$ endodontia veterinária, diferente do que são realizados em odontologia humana, os canais radiculares com polpa mortificada são tratados em apenas uma sessão, devido a que o paciente deve ser submetido à anestesia geral. Desta forma, faz-se necessário buscar um método de anti-sepsia que possa assegurar um elevado grau de descontaminação. Em odontologia humana, pesquisas mostram inúmeras vantagens do emprego de laser associado a substâncias químicas fotossensibilizadoras, denominado de terapia fotodinâmica (Photodynamic Therapy PDT), na redução da microbiota endodôntica. Porém, a endodontia veterinária carece de tais estudos aplicados aos pacientes animais, uma vez que os experimentos realizados em cães sofrem adaptações que simulam a condição clínica do paciente humano, de forma que seus resultados nem sempre podem ser transferidos para a prática veterinária. Logo, a endodontia veterinária carece da avaliação do emprego da terapia fotodinâmica no sistema endodôntico de cães, dentro da prática odontológica veterinária. Justifica-se, então, avaliar o efeito da utilização destes agentes fotossensibilizadores (corantes) quanto a sua eficácia antimicrobiana quando irradiado por luz laser durante o tratamento endodôntico em pacientes da espécie canina. 
2

REVISÃO DE LITERATURA 


\section{REVISÃO DE LITERATURA}

Para a melhor compreensão, a revisão foi subdividida em itens que apresentam a problemática da contaminação microbiológica intracanal e as soluções propostas por diversos autores até chegar ao emprego da terapia fotodinâmica.

\subsection{Tratamento endodôntico convencional}

Segundo Gioso (2003), os casos de tratamento endodôntico de polpas mortificadas (necropulpectomia) compõem a maior parte da prática endodôntica veterinária. A necropulpectomia é realizada em única sessão devido à necessidade de submeter o paciente animal à anestesia geral, não havendo emprego de medicações intracanal entre sessões, que garantem a anti-sepsia e saneamento dos canais, assim como dos tecidos periapicais, na odontologia humana. Portanto, o sucesso da terapia endodôntica está diretamente relacionado aos métodos de esvaziamento e anti-sepsia do sistema de canais radiculares, preconizados por Paiva e Antoniazzi (1973).

O tratamento endodôntico tem como objetivo obter a reparação dos tecidos afetados, permitindo ao dente seu retorno às atividades que the são específicas, tanto estética quanto funcionalmente, o que se chama de processo de cura.

O processo de cura depende fundamentalmente de dois fatores: as condições próprias de reparação do tecido e a presença ou ausência de infecção. Sabe-se que na presença de bactérias, haverá um impedimento para o processo de cura. Portanto, justifica-se a importância da boa qualidade do tratamento endodôntico e criteriosa realização dos passos operatórios. A cirurgia de acesso, quando realizada corretamente, oferece condições adequadas para um bom preparo químico-cirúrgico 
do canal radicular, permitindo que os instrumentos tenham ação em todas as paredes e promovam, juntamente com as substâncias químicas auxiliares, a limpeza e anti-sepsia, além de dar forma adequada, condição que irá proporcionar uma obturação tridimensional e compacta (LEON-ROMAN; GIOSO, 2002).

O tratamento endodôntico pode apresentar falhas quando todos os passos de acesso, limpeza, anti-sepsia e obturação do canal, atualmente preconizados, não são seguidos criteriosamente. A principal razão para que um dente não responda ao tratamento endodôntico está relacionada com erros durante os procedimentos de controle e prevenção da infecção microbiana intracanal. Sem dúvida, o maior fator de falha em tratamentos endodônticos é a infecção microbiana do canal radicular ou do sistema perirradicular. As falhas no controle da infecção podem ocorrer por fratura de instrumentos, perfurações, más obturações, entre outros motivos. Apesar da técnica operatória ser desempenhada de forma ideal, descuidos com o material levado ao canal, ausência de condições assépticas no trans-operatório, contaminações intra ou extra-radiculares estão associados a fatores microbianos (SIQUEIRA JR., 2001).

Quando falhas ocorrem no tratamento endodôntico, sugere-se realizar a desobturação, utilizando-se substância químicas diversas com objetivo de eliminar ou reduzir as bactérias presentes no interior do canal. A literatura mostra que a longo prazo, e dependendo dos fatores envolvidos, com a presença de lesão periapical e do tamanho da lesão, o índice de sucesso do retratamento não passa de $74 \%$ (SUNDQVIST et al., 1998).

$\mathrm{Na}$ endodontia veterinária, Leon-Roman e Gioso (2002) preconizam que a necropulpectomia está dividida em quatro etapas: cirurgia de acesso, anti-sepsia lesvaziamento do canal, obturação/selamento e restauração. A cirurgia de acesso consiste em abordar o sistema de canais radiculares, com emprego de ponta diamantada em caneta de alta rotação, de forma a introduzir as limas endodônticas para o completo esvaziamento do conteúdo mortificado e contaminado dos condutos até o platô apical, assim como para o uso de substâncias químicas auxiliares no processo de desinfecção e saneamento dos condutos. As substâncias químicas auxiliares utilizadas na endodontia veterinária seguem o protocolo proposto por Paiva e Antoniazzi (1973) em endodontia humana, ou seja, hipoclorito de sódio a 
0,5\% (líquido de Dakin) e pasta endodôntica (endo-ptc) a base de peróxido de uréia (10\%), detergente tween80 (15\%) e carbowax (75\%). O hipoclorito de sódio tem propriedade anti-séptica, além de auxiliar na dissolução de debris e restos pulpares por sua capacidade de solubilizar proteinas (SPANO, 1999). O endo-ptc tem a função de lubrificar o conduto, facilitando a instrumentação com as limas endodônticas. Além disso, diminui a tensão superficial, aumentando a molhabilidade do hipoclorito de sódio no interior do canal radicular. As duas substâncias químicas têm ação de sinergismo, produzindo oxigênio nascente, cuja principal função é remover mecanicamente debris presentes no fundo do conduto.

Feito isso, realiza-se o selamento com material obturador à base de resina vegetal (cones de gutta-percha) e cimento endodôntico (óxido de zinco e eugenol). A restauração é realizada na mesma sessão com emprego de resina composta fotopolimerizável (LEON-ROMAN; GIOSO, 2002).

\subsection{Aspectos microbiológicos dos canais radiculares contaminados}

Conhecer a microbiota que habita o sistema endodôntico tem despertado o interesse de muitos pesquisadores. A literatura é rica em publicações na área de microbiologia endodôntica, e faz-se necessária sua revisão.

Buscando correlacionar a presença de microrganismos com alterações pulpares e periapicais, Kakehashi et al. ${ }^{1}$ (1965 apud COHEN; BURNS, 1998, p.437) verificaram que nenhuma alteração patológica ocorria quando da exposição pulpar à cavidade bucal, em ratos livres de germes. Por outro lado, em animais não gnotobióticos, a exposição pulpar levou à necrose e também à formação de lesão

\footnotetext{
1 KAKEHASHI S, STANLEY HR, FITZGERALD RJ. The effects of surgical expousures of dental pulps in germ-free and conventional laboratory rats. Oral Surgery Oral Medicine Oral Patholology Oral Radiolology Endodontology, v. 20, p. 340349, 1965.
} 
periapical. Os autores concluíram que presença ou ausência de microbiota constituiu fator determinante para o desenvolvimento de lesão periapical.

Sundqvist (1976) selecionou 32 dentes anteriores, de pessoas vítimas de trauma dental, e que tiveram suas polpas mortificadas, porém com manutenção da integridade de suas coroas. Desses 32 dentes, 19 apresentavam, radiograficamente, lesão periapical. Utilizando técnicas de anaerobiose para coleta de material, transporte e cultivo, microrganismos foram isolados em 18 dos 19 dentes com lesões periapicais, com média de 6 espécies por canal. A maioria das amostras isoladas (90\%) compunha-se de anaeróbios estritos. Dos 13 dentes restantes sem lesão periapical, não foram isolados microrganismos. Ficou, dessa forma, mais uma vez reconhecida a presença e a significância dos microrganismos no desenvolvimento de lesões periapicais.

Akpata e Blechman (1982) tiveram como proposta investigar in vitro a invasão bacteriana no interior da dentina radicular. Para tal, inocularam em 40 dentes extraídos de pessoas, bactérias conhecidas. Após incubação de 1, 2 e 3 semanas, cortes transversais das raízes foram realizados e avaliados histologicamente. Quanto maior o tempo de incubação, maior foi a invasão do Entercococcus faecalis nos túbulos dentinários, sendo essa mais efetiva em nível do terço cervical, menos no terço médio e ainda menos no terço apical. Os resultados evidenciaram a relação existente entre tempo e invasão bacteriana, bem como, o modo de distribuição dos microrganismos nos diferentes segmentos da dentina radicular.

Fabricius et al. (1982) desvitalizaram 24 dentes de três macacos, deixando os canais radiculares expostos à microbiota bucal durante uma semana, vedando, então, as câmaras pulpares. Amostras foram coletadas em períodos de 90, 180 e 1060 dias. Foi nítido o predomínio de bactérias anaeróbias estritas (85-90\%), especialmente bacilos Gram-negativos, sobre as facultativas (cerca de $2 \%$ ), em função do passar do tempo, sendo essa predominância mais pronunciada no terço apical. Em seis meses foi possível observar, radiograficamente, rarefação óssea periapical. Os autores concluíram que bactérias anaeróbias estritas desempenhavam importante papel no desenvolvimento e manutenção de periodontite apical. 
A presença de bactérias persistentes no sistema de canais radiculares pode levar a uma falha da terapia instaurada. Ando e Hoshiro (1990) avaliaram a capacidade de invasão bacteriana nos túbulos dentinários em dentes contaminados e constataram que o número de anaeróbios cultivados era muito maior do que de aeróbios.

Sundqvist (1992a) estudou o relacionamento entre bactérias no interior do canal radicular. $\mathrm{O}$ autor verificou a existência de relacionamento tipo comensalismo e antagonismo entre determinadas espécies de bactérias coletadas entre 65 pessoas que apresentavam seus canais radiculares com infecção, o que dificultava sua eliminação do canal radicular. $O$ autor constatou que todos os casos apresentavam microbiota predominantemente de anaeróbios (90\%), onde a espécie mais encontrada foi o Fusobacterium nucleatum (48\%) que apresentava associações com outras bactérias, como é o caso da Porphyromonas endodontalis, entre outras. A Prevotella intermedia, que foi encontrada em $34 \%$ dos casos, apareceu associada, entre outros microorganismos, com Eubacterium $s p$, Peptostreptococcus anaerobius. Tais resultados demonstraram a natureza específica da microbiota endodôntica, e também que suas relações podem gerar mudanças populacionais.

No mesmo ano, Sundqvist (1992b) fez uma revisão sobre os fatores ecológicos determinantes da microbiota humana do canal radicular. As bactérias presentes incluíam um grupo restrito de espécies, comparado com o total da microbiota da cavidade oral. Segundo o autor, a viabilidade de nutrientes, as características anatômicas dos canais radiculares portadores de polpa morta, a baixa tensão de oxigênio e as interações bacterianas constituíam importantes fatores de desenvolvimento da microbiota endodôntica.

Siqueira Jr. e Uzeda (1996a) estudaram, in vitro, a desinfecção por pasta de hidróxido de cálcio de túbulos dentinários de dentes humanos infectados com Actinomices israelii, Fusobacterium nucleatum, ou Enterococcus faecalis, microorganismos comuns em infecções endodônticas. As amostras de dentina infectadas foram expostas à pasta de hidróxido de cálcio, associada à solução salina ou paramonoclorofenol canforado, por uma hora, um dia e uma semana. A pasta de hidróxido de cálcio associada ao paramonoclorofenol canforado foi efetiva em 
eliminar bactérias após o período de uma hora, com exceção para as amostras de Enterococcus faecalis, que só foram eliminadas após um dia de exposição ao medicamento. A pasta de hidróxido de cálcio associada à solução salina não foi efetiva contra Enterococcus faecalis, e Fusobacterium nucleatum, mesmo após uma semana de exposição ao medicamento.

No mesmo ano, Siqueira Jr. et al. (1996b) avaliaram a capacidade de penetração microbiana na dentina radicular através de microscopia eletrônica de varredura. Para tal experimento foram selecionadas cepas microbianas de Porphyromonas endodontalis, Fusobacterium nucleatum, Actinomices israelii, Porphyromonas gingivalis, Propionibacterium acnes e Enterococcus faecalis, as quais foram inoculadas em dentina bovina por 21 dias. Os autores observaram capacidade de infiltração dentinária para todos os microorganismos, com especial atenção para Enterococcus faecalis, Propionibacterium acnes e Actinomices israelii.

Ayhan et al. (1999) testaram várias substâncias utilizadas durante a antisepsia dos canais radiculares contra Staphylococcus aureus, Enterococcus faecalis, Streptococcus salivarius, Streptococcus pyogene, Escherichia coli e Candida albicans. Discos de papel de $6 \mathrm{~mm}$ de diâmetro, previamente esterilizados, foram umedecidos com as soluções testadas e aplicados em placas de Petri com meio Ágar. A zona de inibição foi mensurada para cada placa. Quando comparadas com álcool a $21 \%$, as soluções de $\mathrm{NaOCl}$ a $0,5 \%$ e clorexidina a $2 \%$, assim como o paramonoclorofenol, mostraram uma grande ação antimicrobiana, porém, a solução de $\mathrm{NaOCl}$ a $5,25 \%$ foi superior em sua habilidade antimicrobiana quando comparada com as demais soluções. A solução de menor concentração de $\mathrm{NaOCl}$ (a $0,5 \%)$ resultou em significante diminuição de sua capacidade antimicrobiana.

Marais e Williams (2001) avaliaram in vitro a efetividade da água eletricamente energizada como solução irrigante. Foram utilizados 60 dentes humanos esterilizados, divididos em quatro grupos, onde foram inoculadas duas cepas de bactérias anaeróbias obrigatórias (Prevotella intermedia e Porphyromonas gingivalis) e duas cepas de anaeróbios facultativos (Enterococcus faecalis e Actinobacillus actinomycetemcomitans). Foram comparadas soluções de água eletricamente energizada em pH 7,0 e 9,0 com $\mathrm{NaOCl}$. Após a realização de contagem de unidades formadoras de colônia (UFC) e análise espectrofotométrica, a 
água energizada apresentou diminuição do número de colônias, porém com efetividade inferior quando comparada ao $\mathrm{NaOCl}$.

Peters e Wesselink (2002) avaliaram a cura da lesão periapical em dentes humanos com cultura positiva e negativa no momento da obturação, e a cura da lesão periapical em dentes tratados em uma sessão ou duas sessões, onde houve a aplicação de medicação intracanal com hidróxido de cálcio. Trinta e nove pacientes receberam tratamento endodôntico. $\mathrm{Na}$ primeira sessão os dentes foram instrumentados, e 18 dentes foram preenchidos, após coleta microbiológica intracanal, com hidróxido de cálcio em solução salina. Outros 21 dentes foram obturados com gutta-percha e cimento AH-26 após coleta microbiológica intracanal. Após quatro semanas, os dentes preenchidos com medicação intracanal tiveram suas raízes novamente acessadas e, após coleta microbiológica, foram obturados. $\mathrm{O}$ acompanhamento da cura da lesão periapical foi realizado através de avaliação radiográfica. No final do experimento, os autores concluíram que não houve diferença significativa nos grupos em que se realizou o tratamento endodôntico em uma ou duas sessões após quatro semanas. Também concluíram que a presença de microorganismos no momento da obturação não influenciou o resultado final do tratamento.

Peters et al. (2002) realizou coleta intracanal de dentes humanos para microorganismos anaeróbios, em 58 pacientes com lesão periapical e sem sinais ou sintomas clínicos, e posteriormente, contagem e identificação das espécies encontradas. Ao final do trabalho, concluiu que $87 \%$ da microbiota intracanal estava composta por bactérias anaeróbias estritas. As bactérias mais prevalentes foram Prevotella intermedia, Peptostreptococcus micros e Actinomyces odontolyticus, presentes nas culturas realizadas em 33, 29 e 19\% respectivamente. Após avaliação estatística, encontrou relação significante entre $P$. intermedia e P.micros, $P$. intermedia e P.oralis, A.odontolyticus e P.micros, Bifidobacterium spp e Veillonella spp, concluindo que estes patógenos não ocorrem aleatoriamente, mas sim em combinações específicas.

Pinheiro et al. (2003) identificaram a microbiota dos canais radiculares de dentes humanos que apresentavam falha no tratamento de canal e relacionaram com os achados clínicos. Sessenta dentes tratados endodonticamente nos quais 
persistia a lesão periapical foram selecionados. Durante o re-tratamento, o material obturador foi removido e foram realizadas coletas microbiológicas. Foram encontrados microorganismos em 51 dentes. Das espécies isoladas, $57,4 \%$ eram anaeróbios facultativos e $83,3 \%$ gram-positivos, sendo o Enterococcus faecalis a espécie mais encontrada. Microorganismos anaeróbios obrigatórios compunham $42,6 \%$ das espécies, sendo que o gênero Peptostreptococcus foi mais freqüentemente isolado. Os autores observaram significante relação entre: dor e infecções polimicrobianas ou anaeróbios; sensibilidade à percussão e Provetella intermedia / P.nigrescens; abscesso e Streptococcus spp ou Actinomyces spp; falha de selamento coronal e Streptococcus spp ou Candida spp.

Önçağ et al. (2003) compararam a toxicidade e propriedades antibacterianas do $\mathrm{NaOCl}$ a $5,25 \%$, gluconato de clorexidina a $0,2 \%$, gluconato de clorexidina $0,2 \%$ com brometo de cetrimida (amônio quaternário). Foi inoculado Enterococcus faecalis em 60 dentes humanos unirradiculares recém-extraídos, e realizada avaliação microbiológica após cinco minutos e 48 horas da inoculação. Os mesmos irrigantes foram testados em estudo separado in vivo, durante a "desinfecção" de dentes decíduos com polpa mortificada. Além disso, as soluções foram injetadas em subcutâneo de ratos para testar a toxicidade, avaliando-se a reação inflamatória em duas horas, 48 horas e duas semanas após a aplicação. Em laboratório, o gluconato de clorexidina a $0,2 \%$ associado à cetrimida foram significantemente mais efetivos sobre Enterococcus faecalis que o $\mathrm{NaOCl}$ a $5,25 \%$ aos cinco minutos de sua aplicação intracanal. Da mesma forma, no estudo in vivo, o gluconato de clorexidina a $0,2 \%$ associado à cetrimida foram significantemente mais efetivos sobre bactérias anaeróbias que o $\mathrm{NaOCl}$ a $5,25 \%$ às 48 horas de sua aplicação. Ao fim de duas semanas, o $\mathrm{NaOCl}$ apresentava maior toxicidade quando comparado às outras soluções irrigantes.

Radcliffe et al. (2004) determinaram a resistência do Actinomyces naes/undii, Candida albicans e Enterococcus faecalis associados com infecções endodônticas refratárias ao emprego do hipoclorito de sódio usado como irrigante durante o tratamento endodôntico, em diferentes concentrações $(0,5,1,0,2,5$ e $5,25 \%)$ e tempo $(0,10,20,30,60$ e 120 segundos). No caso do Enterococcus faecalis foram avaliados os tempos adicionais de um, dois, cinco, 10 e 30 minutos. Todas as concentrações de $\mathrm{NaOCl}$ diminuíram significantemente o número de UFC após 10 
segundos nos casos de Actinomyces naeslundii e Candida albicans, porém o Enterococcus faecalis mostrou-se mais resistente, mostrando redução a zero unidades formadoras de colônia (UFC) em 30 minutos para concentração de 0,5\%, 10 minutos para 1,0\%, 5 minutos para 2,5\% e 2 minutos para 5,25\%. Os autores concluíram que o E.faecalis apresenta resistência ao $\mathrm{NaOCl}$ e está associado aos casos de insucesso no tratamento endodôntico.

Menezes et al. (2004) avaliaram in vitro a efetividade do hipoclorito de sódio a $2,5 \%$, clorexidina a 2,0\%, hidróxido de cálcio, paramonoclorofenol canforado, tricresol formalina, paramonoclorofenol associado ao furacin em 95 dentes humanos unirradiculares extraídos e esterilizados, onde foram inoculados Candida albicans e Enterococcus faecalis. Os pesquisadores concluíram que o hidróxido de cálcio associado ao paramonoclorofenol canforado foi mais efetivo como medicação intracanal para os dois microorganismos, e que a clorexidina 2,0\% foi mais efetiva que o $\mathrm{NaOCl}$ a 2,5\% contra Enterococcus faecalis.

Ferrari et al. (2005) avaliaram 25 dentes humanos unirradiculares com polpa mortificada e lesão periapical. Coletas dentro do canal foram realizadas antes e depois da instrumentação. Entre os microorganismos isolados, foram identificadas para avaliação enterococi, bactérias entéricas e leveduras, através de teste bioquímico. Os microorganismos foram isolados de $92 \%$ das amostras, após o acesso intracoronal, sendo $22 \%$ enterococci, bactérias entéricas ou leveduras. Após o preparo biomecânico, estas espécies não foram detectadas. Após sete dias sem medicação intracanal, $100 \%$ dos canais continham microorganismos, sendo que $52 \%$ eram pertencentes às espécies estudadas. Porém, após o uso de paramonoclorofenol glicol como medicação intracanal, após sete dias não foram detectadas bactérias entéricas e leveduras. Somente enterococci ainda estavam presentes. Os autores concluíram que os enterococci, bactérias entéricas e leveduras estão presentes em infecções intracanais primárias, e que os enterococci, particularmente Enterococcus faecalis e E.faecium foram resistentes à remoção pelo preparo biomecânico seguido de medicação intracanal.

Em odontologia humana, com objetivo de evitar a disseminação da infecção e o risco de infecção sistêmica, diversos antibióticos têm sido administrados, o que levou à seleção de bactérias resistentes a estes fármacos. Bactérias como o 
Enterococcus faecalis, descrita como sendo de difícil eliminação, vêm se tornando resistente a diversos antibióticos como eritromicina, ampicilina, benzilpenicilina, clindamicina, metronidazol, tetraciclina (DAHLEN et al., 2000) assim como resistente, também a antimicrobianos como o hidróxido de cálcio, paramonoclorofenol canforado, clorexidina e hipoclorito de sódio (AYHAN et al., 1999). Possivelmente o mesmo tipo de resistência esteja sendo induzida em pacientes animais, visto que, pelo desconhecimento da odontologia veterinária por muitos profissionais e proprietários, existe o "costume" de prescreverem-se antibióticos para problemas orais sem certeza do diagnóstico.

\subsection{Laser de baixa potência}

Juntamente com a evolução dos materiais e técnicas, a laserterapia vem conquistando espaço na medicina, odontologia e medicina veterinária. $\mathrm{Na}$ endodontia humana, este avanço tecnológico vem contribuindo não somente com a redução do tempo de trabalho clínico, mas também em aspectos biológicos do tratamento, como em alterações morfológicas das estruturas dentais (esmalte e dentina) e na redução significativa dos microorganismos presentes no sistema de canais radicualres e, por conseqüência, no sucesso do tratamento endodôntico em dentes portadores de lesões periapicais (NIKOLAOS et al., 2006).

A radiação em questão é eletromagnética não-ionizante, com comprimento de onda $(\lambda)$ entre 300 e $600 \mathrm{~nm}$, com características bastante distintas. A radiação laser é monocromática, ou seja, apresenta um único comprimento de onda. Apresenta coerência temporal e espacial, isto é, propaga-se com mesma fase no espaço e tempo, além de concentrar uma alta densidade de energia concentrada em pequenos pontos (BRUGNERA JR.; PINHEIRO, 1998).

A radiação do laser pode ser refletida, absorvida, transmitida ou espalhada pelo tecido. A absorção seletiva por parte dos tecidos é determinada pelo 
comprimento de onda do laser, fenômeno denominado de ressonância a uma determinada freqüência. Desta forma, para cada comprimento de onda encontra-se um tipo diferente de interação entre o tecido e a radiação laser (BRUGNERA JR.; PINHEIRO, 1998).

A laserterapia pode ser realizada com laser de alta ou baixa intensidade. Desta forma, existe a HILT (High-intensity laser therapy) e LILT (Low-intensity laser therapy).

Os lasers comumente utilizados (Er:YAG, Er,Cr:YSGG, Nd:YAG, Ho:YAG e diodo) são lasers de alta potência e por isso o risco de aumento de temperatura intracanal ou radicular não pode ser negligenciado (GUTKNECHT et al., 1996). A produção de fumaça tem grande potencial de disseminar contaminação bacteriana intracanal ao paciente e toda equipe cirúrgica, motivo que obriga o uso de sistema de sucção à vácuo durante o uso do laser cirúrgico no canal radicular contaminado (MCKINLEY et al., 1994). Além disso, os lasers de alta potência têm custo relativamente alto, o que os torna inviável para a grande maioria dos médicos veterinários.

Os lasers em baixa intensidade apresentam potências inferiores aos de alta intensidade, tendo potência média entre 30 a $100 \mathrm{~mW}$, com modo de emissão contínua ou pulsátil, variando em comprimentos de onda entre 630 a 904nm. Não produzem efeitos térmicos aos tecidos. Sua aplicação baseia-se na quantidade de luz absorvida, que produz reações fotoquímicas ou fotofísicas, diferentemente do laser de alta intensidade, cuja ação está baseada na promoção de efeitos térmicos.

A LILT pode ser definida como tipo de terapia não-térmica, capaz de causar alterações celulares e teciduais, geradas pelo processo de biomodulação, ou seja, inativação ou ativação de processos metabólicos.

Segundo Utsonomiya (1998), dentro da endodontia humana, o laser em baixa intensidade já vem sendo utilizado no capeamento pulpar direto quando aplicado diretamente sobre a exposição pulpar, antes da aplicação do hidróxido de cálcio, com objetivo de bioestimulação dos odontoblastos, aumento da velocidade de formação da dentina reparacional, analgesia e redução do processo inflamatório; pós-operatório após o preparo biomecânico para reduzir a sensibilidade pós- 
instrumentação, biomodulação dos tecidos periapicais e promover maior reparação óssea periapical.

\subsection{Conceito da Terapia Fotodinâmica}

A luz tem sido utilizada no tratamento de doenças desde a antigüidade. Os indianos, egípcios e chineses já tratavam doenças da pele como psoríase, vitiligo e câncer com a exposição do paciente ao sol, o que o filósofo grego Heródoto chamava de helioterapia. As primeiras experiências com a terapia fotodinâmica datam de mais de 100 anos atrás, realizadas no laboratório de Von Tappeiner, em Munique, relatadas por seu aluno de medicina, Oscar Raab² (1900 apud PERVAIZ; OLIVO, 2006 p. 551), que observou que baixas concentrações de acridina na presença de luz podiam ser letais aos paramécios.

Durante o tratamento de epilepsia, em 1900, os neurologistas Jouve e Boyer administraram eosina por via oral ao pacientes e verificaram que os mesmos apresentavam dermatites nas áreas expostas ao sol. Este trabalho motivou Von Tappeiner e Jesionek a utilizar uma combinação de eosina, aplicada topicamente, com exposição à luz branca para o tratamento de tumores cutâneos. Em 1907, Von Tappeiner denominou este fenômeno de ação fotodinâmica.

Desde então, as pesquisas nesta área, principalmente no combate ao câncer, buscam novos fotossensibilizantes e novas fontes de luz.

\footnotetext{
${ }^{2}$ RAAB, O.; Über die Wirkung Fluoreszierender Stoffen auf Infusoria. Zeitschrift für Biologie, v.39, p.524-526, 1900.
} 


\subsection{Ação da terapia fotodinâmica em microorganismos}

Em pesquisa utilizando o corante toluidina-O irradiado por luz branca de xenônio em cultura de Saccharomyces cerevisiae, Ito (1980) avaliou o dano celular ocorrido na membrana celular através das medidas de fluxo de uma sonda molecular. Concluiu que a permeabilidade da célula aumentou drasticamente pela ação fotodinâmica, promovendo o fluxo do corante para o interior celular.

Malik et al. (1990) afirmam que as diferenças estruturais existentes entre os diferentes tipos de bactérias devem ser levadas em consideração. Em geral, bactérias Gram-positivas desenvolvem a fotossensibilização mediante produção de oxigênio singleto $\left({ }^{1} \mathrm{O}_{2}\right)$, enquanto as bactérias anaeróbias são fotossensibilizadas sem este último, mas sim pela formação de radicais livres. No entanto, Gramnegativas devem ser tratadas com substâncias que promovam o rompimento das estruturas de sua membrana. Os pesquisadores afirmam, ainda, que para ocorrer a inativação do microorganismo, o fotossensibilizante deve ser absorvido pela parede celular, unir-se à membrana interna da célula e difundir-se pelo citoplasma celular, promovendo a inibição da síntese de DNA, RNA e proteínas.

Okamoto et al. (1992) investigaram in vitro o efeito antimicrobiano do laser de $\mathrm{He}-\mathrm{Ne}$ associado a diversos corantes sobre microorganismos cariogênicos. Os autores testaram o efeito antimicrobiano do laser de He-Ne quando combinado com dez tipos de corantes (azuis, roxos e verdes) em espectroscopia de absorção atômica, espectroscopia ultravioleta e zona de inibição de crescimento em placas de cultura. Verificou-se neste estudo que os efeitos letais sobre os microorganismos eram efetivos, apenas quando corantes específicos foram utilizados.

Paardekooper et al. (1995) estudaram o efeito da FLL em complexos enzimáticos intracelulares utilizando 0 azul de toluidina. Os resultados demonstraram que ocorria uma inibição destes complexos enzimáticos e uma queda nos níveis de adenosina trifosfato (ATP), inviabilizando a célula.

Wainwright (1998) sugere que, quando um microorganismo demonstra seletividade por um corante como o azul de metileno, este deve ser passível de ser 
fotossensibilizado. $\mathrm{O}$ autor explica que se um corante absorve a energia gerada por uma fonte de luz, pode ocorrer uma transição de elétrons para um estado singleto excitado. Assim, dependendo da estrutura molecular e do meio onde está ocorrendo essa transferência eletrônica, a molécula pode perder sua energia através de processo físico, voltando desta forma ao seu estado fundamental, ou ainda passar para um estado excitado tripleto. A partir daí, a molécula pode cair novamente para o seu estado fundamental, sofrer reações de óxido-redução com o meio, ou então sua energia pode ser transferida para o oxigênio molecular, resultando na formação de oxigênio singleto.

Quadro 1 - Vias fotocitotóxicas nas células microbianas

\begin{tabular}{|c|c|c|c|c|}
\hline Área de ação & Ação & Resultado & Conseqüência & Evento citotóxico \\
\hline Água & $\begin{array}{l}\text { Abstração do } \\
\text { hidrogênio } \\
\text { Peroxidação }\end{array}$ & $\begin{array}{l}\text { Formação do radical } \\
\text { hidroxila } \mathrm{OH}^{-}\end{array}$ & $\begin{array}{c}\text { Formação de peróxido } \\
\text { de hidrogênio } \\
\text { superóxido }\left(\mathrm{O}_{2}^{-}\right)\end{array}$ & $\begin{array}{c}\text { Processos oxidativos } \\
\text { adicionais }\end{array}$ \\
\hline $\begin{array}{l}\text { Parede / membrana } \\
\text { celular } \\
\text { Lipídeos e esteróis } \\
\text { insaturados }\end{array}$ & $\begin{array}{l}\text { Abstração do } \\
\text { hidrogênio }\end{array}$ & $\begin{array}{c}\text { Peroxidação } \\
\text { Ligação cruzada } \\
\text { peptídeo }\end{array}$ & $\begin{array}{c}\text { Formação de } \\
\text { hidroperóxido } \\
\text { Inativação enzimática }\end{array}$ & $\begin{array}{c}\text { Permeabilidade } \\
\text { aumentada aos íons } \\
\text { (perda } \mathrm{Na}^{+} / \mathrm{K}^{+} \text {) }\end{array}$ \\
\hline Peptídeos & $\begin{array}{l}\text { Oxidação dos } \\
\text { resíduos Tyr/Met/His }\end{array}$ & Degradação protéica & & $\begin{array}{c}\text { Perda de facilidade de } \\
\text { reparo; lise }\end{array}$ \\
\hline $\begin{array}{c}\text { Cobertura Protéica } \\
\text { viral }\end{array}$ & $\begin{array}{l}\text { Reações de óxido- } \\
\text { redução } \\
\text { (REDOX) }\end{array}$ & & & Inibição da respiração \\
\hline Cadeia respiratória & $\begin{array}{l}\text { Oxidação ou ligações } \\
\text { cruzadas }\end{array}$ & & & Inibição da respiração \\
\hline $\begin{array}{c}\text { Enzimas } \\
\text { citoplasmáticas / } \\
\text { enzimas virais } \\
\text { (transcriptase reversa) }\end{array}$ & & & & $\begin{array}{c}\text { Inibição do conjunto } \\
\text { ribossômico; Inibição } \\
\text { da replicação, } \\
\text { infectividade }\end{array}$ \\
\hline $\begin{array}{l}\text { Resíduos de ácidos } \\
\text { nucléicos } \\
\text { (guanosina) }\end{array}$ & $\begin{array}{c}\text { Oxidação da base ou } \\
\text { do açucar }\end{array}$ & 8-hidroxiguanosina & $\begin{array}{c}\text { Degradação de } \\
\text { nucleotídeo; } \\
\text { degradação do } \\
\text { açúcar/clivagem }\end{array}$ & $\begin{array}{l}\text { Substituição da base; } \\
\text { clivagem; partição; } \\
\text { mutação; inibição da } \\
\text { replicação }\end{array}$ \\
\hline
\end{tabular}

Fonte: Wainwright, 1998. 


\subsection{Aspectos clínicos da Terapia Fotodinâmica}

A literatura demonstra que o uso de corantes deve ocorrer de forma que a banda de absorção dos fotoiniciadores esteja em ressonância com o comprimento de onda emitido pela fonte de luz. Para isto, diversos corantes vêm sendo testados, nas cores azuis, roxas, marrons, verdes entre outras. A busca por agentes fotossensibilizadores tem então sido uma constante no campo da terapia fotodinâmica, tanto para o tratamento de neoplasias como para a eliminação de microorganismos. Corantes menos tóxicos, mais ressonantes com o comprimento de onda emitidos pelos lasers têm sido o ideal de diversos investigadores. $E$ quanto mais próximos deste ideal novos agentes se mostrarem, mais a terapia fotodinâmica realizará seu potencial na redução microbiana (KÖNIG et al., 2000).

Dobson e Wilson (1992) avaliaram vinte e sete fotossensibilizantes em concentrações variadas associados ao laser de Hélio-Neônio (He-Ne) e sua capacidade de inibir 0 crescimento de bactérias Actinobacilus actinomycetencomitans, Streptococcus sanguis, Fusobacterium nucleatum e Porphyromonas gingivalis. Os pesquisadores concluíram que os corantes azul de toluidina e azul de metileno foram eficazes em eliminar as quatros espécies bacterianas e os corantes ftalocianina dissulfonada de alumínio, hematoporfirina $\mathrm{HCl}$ e hematoporfirina éster somente foram efetivos em sensibilizar alguns dos microorganismos. Desta forma, afirmam que a técnica de terapia fotodinâmica pode ser efetiva em eliminar bactérias patogênicas periodontais que compõe a placa bacteriana.

Culturas de Actinobacilus actinomycetencomitans, Fusobacterium nucleatum e Porphyromonas gingivalis foram tratadas com uma diversidade de agentes fotossensibilizadores e expostas a laser de He-Ne de potência de 7,5mW por até 80 segundos. Wilson et al. (1993) concluíram que o azul de orto-toluidina (O-toluidina) e o azul de metileno na mesma concentração $(25 \mu \mathrm{g} / \mathrm{mL})$ foram letais para as três culturas microbianas. Na ausência de luz laser os corantes mostraram-se ineficazes.

Seal et al. (2002) compararam azul de O-toluidina em diferentes concentrações, irradiado por laser, com irrigação por hipoclorito de sódio a 3\%. Foram utilizados 35 dentes humanos unirradiculares extraídos e esterilizados. Foi 
inoculado Streptococcus intermedius por 48 horas até a formação de um biofilme. Os autores concluíram que o uso do fotossensibilizante e laser em baixa intensidade são bactericidas eficazes para o biofilme de S.intermedius, porém não alcançaram anti-sepsia semelhante ao $\mathrm{NaOCl}$ a $3 \%$.

Hayek et al. (2005) compararam a terapia fotodinâmica com as técnicas convencionais no tratamento das peri-implantites. Foram extraidos 18 pré-molares de cão Labrador retriever e aplicados implantes nos respectivos alvéolos. Após o período de osteointegração, foram aplicadas ligaduras ao redor dos dentes para indução de peri-implantite. Passados quatro meses, as ligaduras foram removidas e os animais foram divididos em dois grupos, um para tratamento convencional com uso de clorexidina e raspagem peri-implantar e o outro para aplicação do fotossensibilizante azuleno, irradiado por laser de baixa intensidade Gálio-AlumínioArsênio (GaAlAs) com $\lambda=660 \mathrm{~nm}, \mathrm{P}=40 \mathrm{~mW}, \mathrm{E}=7.2 \mathrm{~J}$, por três minutos. Foram realizadas coletas microbiológicas antes e depois do tratamento. Os resultados mostraram que Provetella $s p$, Fusobacterium $s p$ e S.beta-haemolyticus foram significantemente reduzidos em ambos grupos. Os pesquisadores concluíram que a terapia fotodinâmica pode ser considerada um método não-invasivo no tratamento das peri-implantites.

Garcez et al. (2006) investigaram a ação do laser em baixa intensidade associado a um fotossensibilizante na redução de Entereococcus faecalis em canais radiculares in vitro. Foram contaminados 30 dentes humanos unirradiculares $\mathrm{e}$ divididos em dois grupos. O primeiro foi irrigado com $\mathrm{NaOCl}$ a $0,5 \%$ e deixou-se a solução por 30 minutos. No outro grupo, o canal foi preenchido com o agente fotossensibilizante, mantido por cinco minutos e, logo após, irradiado por laser com comprimento de onda de $685 \mathrm{~nm}$ por três minutos, com emprego de fibra óptica. Após os estudos, os pesquisadores afirmaram que o fotossensibilizante ou laser isolados não apresentam propriedades antimicrobianas. $\mathrm{O} \mathrm{NaOCl}$ a $0,5 \%$ alcançou $93,25 \%$ de desinfecção, enquanto que o laser associado à fotossensibilização obteve $99,2 \%$ de sucesso. O estudo afirma que a fotossensibilização foi efetiva durante a redução de E.faecalis, e sugere que seja adjuvante do tratamento endodôntico. 
Bonsor et al. (2006) experimentaram utilizar azul de O-toluidina associada à irradiação de laser em baixa intensidade in vivo. Foram eleitos 30 pacientes de forma randômica, que apresentavam lesão endodôntica. Foi realizada coleta microbiológica intracanal imediatamente após o acesso, e apenas 20 apresentavam microorganismos. Destes, 16 dentes apresentaram resultado negativo na cultura em placa após o tratamento endodôntico convencional. Os quatro dentes restantes que ainda apresentavam microorganismos após o tratamento endodôntico convencional, apresentaram resultado negativo na cultura após aplicação do agente sensibilizante irradiado com laser. Os autores concluíram que a terapia fotodinâmica proporciona a destruição de microorganismos refratários ao uso de substâncias químicas convencionais na terapia endodôntica.

Nikolaos et al. (2006) testaram os efeitos da terapia fotodinâmica sobre microorganismos patógenos. Em 60 dentes humanos recém-extraídos, foi introduzida solução de azul de metileno, permanecendo em repouso por 5 minutos e, posteriormente, sofrendo irradiação de laser diodo com $\lambda=665 \mathrm{~nm}$ e $E=30 \mathrm{j} / \mathrm{cm}^{2}$ através de introdução de fibra óptica para irradiação tridimensional da luz dentro do conduto. Neste protocolo, foram eliminadas todas as bactérias, exceto Enterococcus faecalis ( $53 \%$ de eliminação). Ao aumentar a potência para $\mathrm{E}=222 \mathrm{~J} / \mathrm{cm}^{2}$, houve $97 \%$ de eliminação de E.faecalis. Os autores concluíram que a terapia fotodinâmica deve ser empregada como coadjuvante do tratamento endodôntico padrão.

Qin et al. (2008) compararam in vivo a fotossensibilização do azul de toluidina com o tratamento periodontal convencional, por raspagem, em ratos. Foram utilizadas ligaduras subgengivais em 16 molares superiores de ratos. Após seis semanas, a infecção foi tratada com $1 \mathrm{mg} / \mathrm{ml}$ de azul de toluidina, irradiado por luz laser a $12 \mathrm{~J} / \mathrm{cm}^{2}$, ou por raspagem periodontal. A eficácia foi avaliada pela redução de bactérias totais da microbiota e por alterações histológicas do tecido periodontal. Houve significante redução bacteriana em ambas as terapias. Os autores concluíram que a terapia fotodinâmica com azul de toluidina pode ser empregada no tratamento da periodontite e tem alto potencial clínico de aplicação. 
3 


\section{OBJETIVO}

A presente pesquisa teve por objetivo avaliar in vivo a redução microbiana dos canais radiculares de dentes de cães portadores de necrose pulpar e lesão periapical, comparando a eficácia do hipoclorito de sódio a $0,5 \%$, usado como substância química auxiliar no preparo químico-cirúrgico convencional, e o uso de fotossensibilizante irradiado por laser de baixa potência, em diferentes momentos de aplicação.

Foi considerada a seguinte hipótese experimental: a irradiação do fotossensibilizante azuleno com laser de baixa intensidade tem grande capacidade de redução microbiológica, podendo ser utilizado como coadjuvante do protocolo convencional de limpeza e anti-sepsia (hipoclorito de sódio 0,5\% + endo-ptc) dos canais radiculares em cães, elevando as chances de sucesso do tratamento endodôntico na prática odontológica veterinária. 
4 


\section{MATERIAL E MÉTODO}

Vinte cães, adultos, com idade entre três e 11 anos, machos e fêmeas, provenientes do Hospital Veterinário da Faculdade de Medicina Veterinária e Zootecnia da Universidade de São Paulo (HOVET-FMVZ/USP) foram utilizados. Os animais foram atendidos nas dependências do Laboratório de Odontologia Comparada (LOC-FMVZ/USP), onde todos os procedimentos odontológicos foram realizados.

Todo o material e equipamentos utilizados no desenvolvimento deste trabalho foram obtidos mediante Auxílio à Pesquisa da FAPESP (protocolo 04/12154-3).

\subsection{Seleção dos dentes}

Um dente unirradicular de cada animal foi selecionado de acordo com os apêndices $C$ e D, obedecendo aos seguintes critérios de inclusão:

- Dentes portadores de rizogênese completa.

- Câmara pulpar exposta ou não à cavidade oral (Fig. 1).

- Diagnóstico clínico de necrose pulpar (Fig. 1).

- Presença de rarefação óssea periapical, visível ao exame radiográfico (Fig. 2).

- Ausência de doença periodontal.

- Não estar fazendo uso de antibióticos, minimamente, nos três últimos meses. 


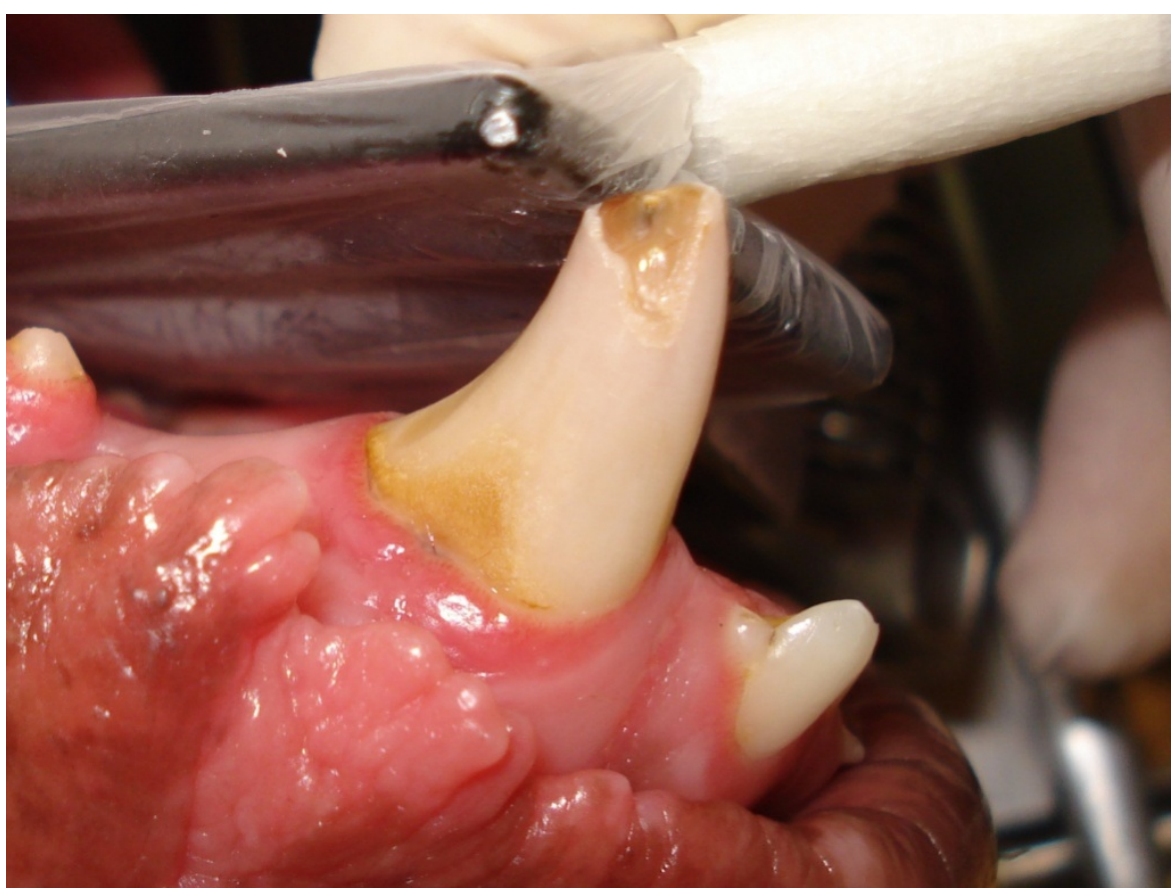

Figura 1- Canino inferior direito, apresentando fratura da coroa com exposição do canal radicular, leve escurecimento dentário e conteúdo mortificado no interior do conduto

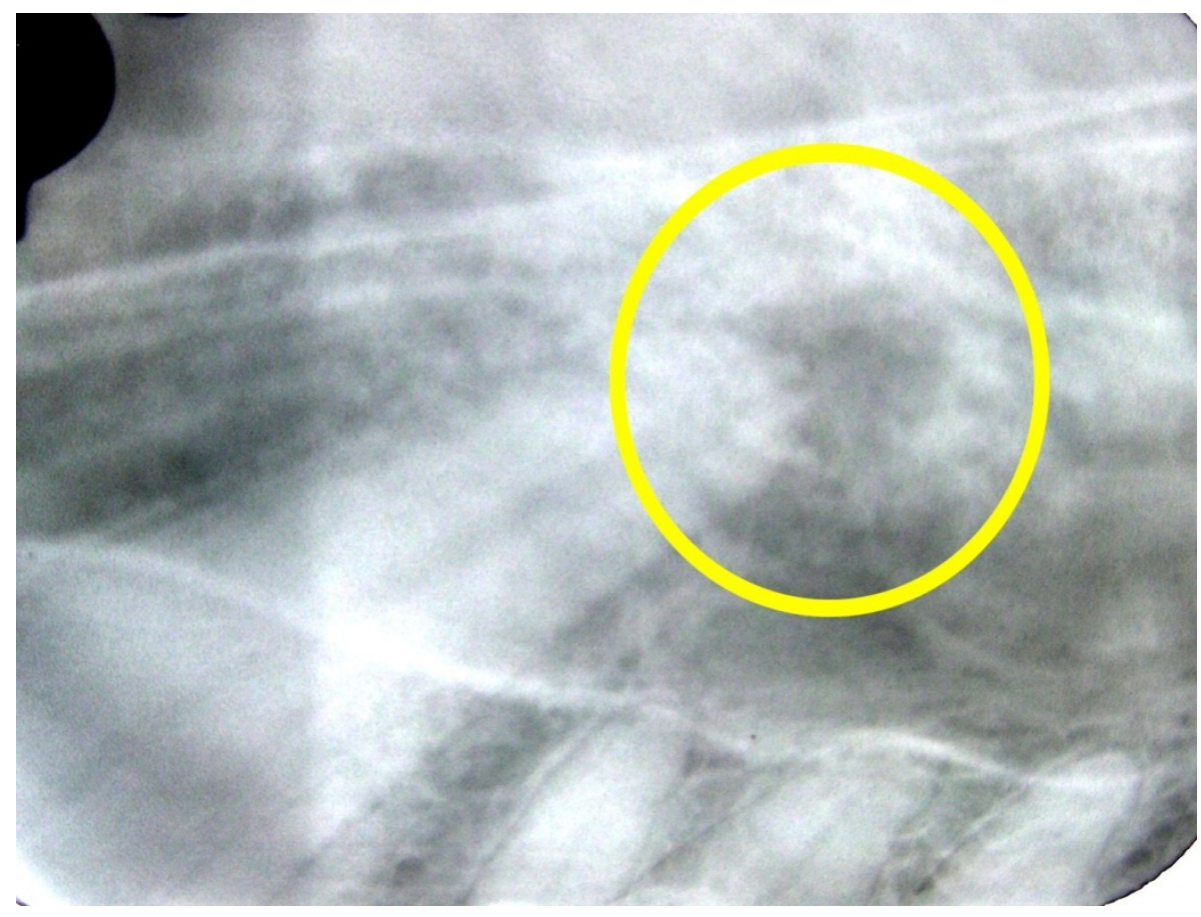

Figura 2- Radiografia intra-oral de dente canino superior esquerdo, onde o halo de radioluscência (em destaque) sugere área de rarefação óssea periapical, compatível com lesão endodôntica seguida de morte e contaminação pulpar 


\subsection{Equipamento Laser}

O equipamento laser utilizado neste experimento foi um laser de GálioAlumínio-Arsênio (GaAlAs), modelo KO 650 Kroman (São Paulo, Brasil), comprimento de onda de $670 \mathrm{~nm}$, potência de $50 \mathrm{~mW}$, sistema de entrega de feixe por fibra óptica de $365 \mu \mathrm{m}$ (Fig. 3) acoplado à ponta de peça de mão do equipamento, desenvolvida pela empresa fabricante do equipamento especificamente para este estudo (Fig. 4).

Os parâmetros utilizados neste estudo foram os seguintes:

- Potência $50 \mathrm{~mW}$

- Intensidade aproximada $10 \mathrm{~W} / \mathrm{cm}^{2}$

- Dose $4 \mathrm{~J} / \mathrm{cm}^{2}$

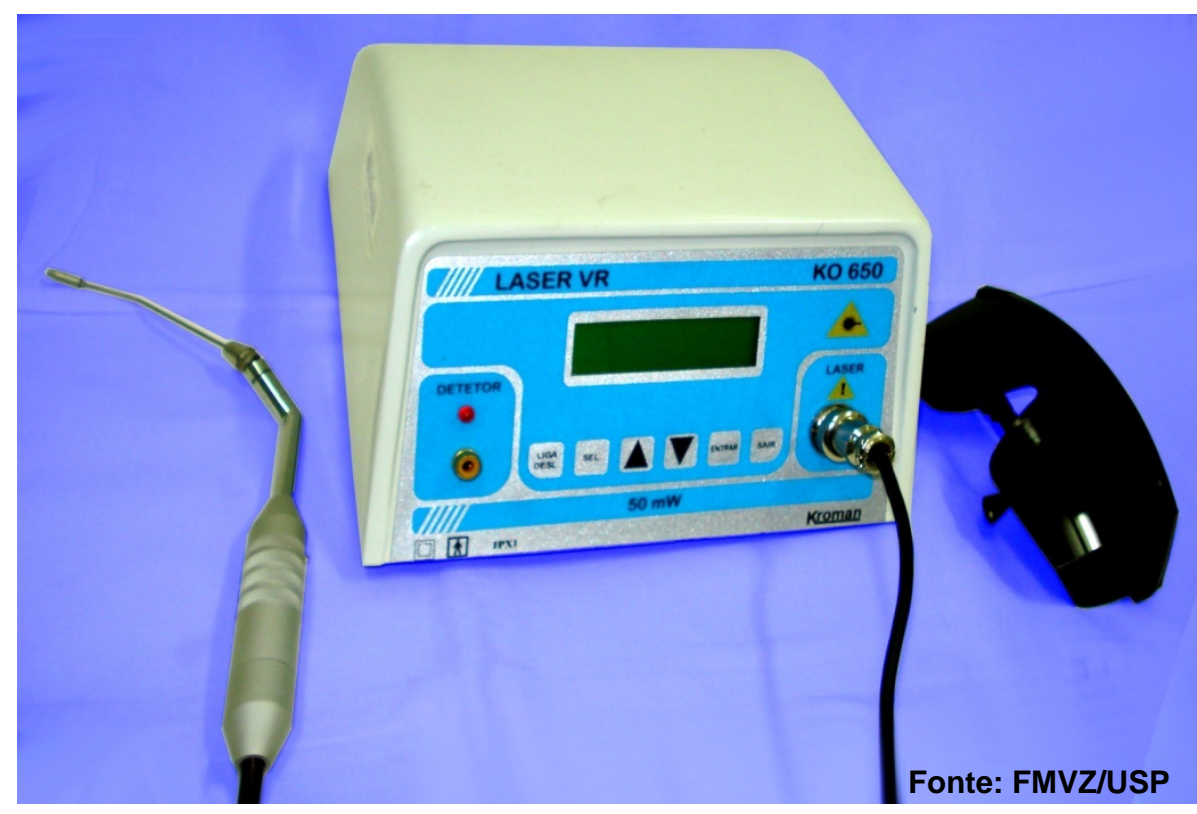

Figura 3 - Equipamento laser utilizado no experimento, modelo KO650 (Kroman, São Paulo, Brasil), acompanhado da ponteira acoplada à peça-de-mão, além do óculos de proteção, de uso obrigatório durante a irradiação da luz laser 


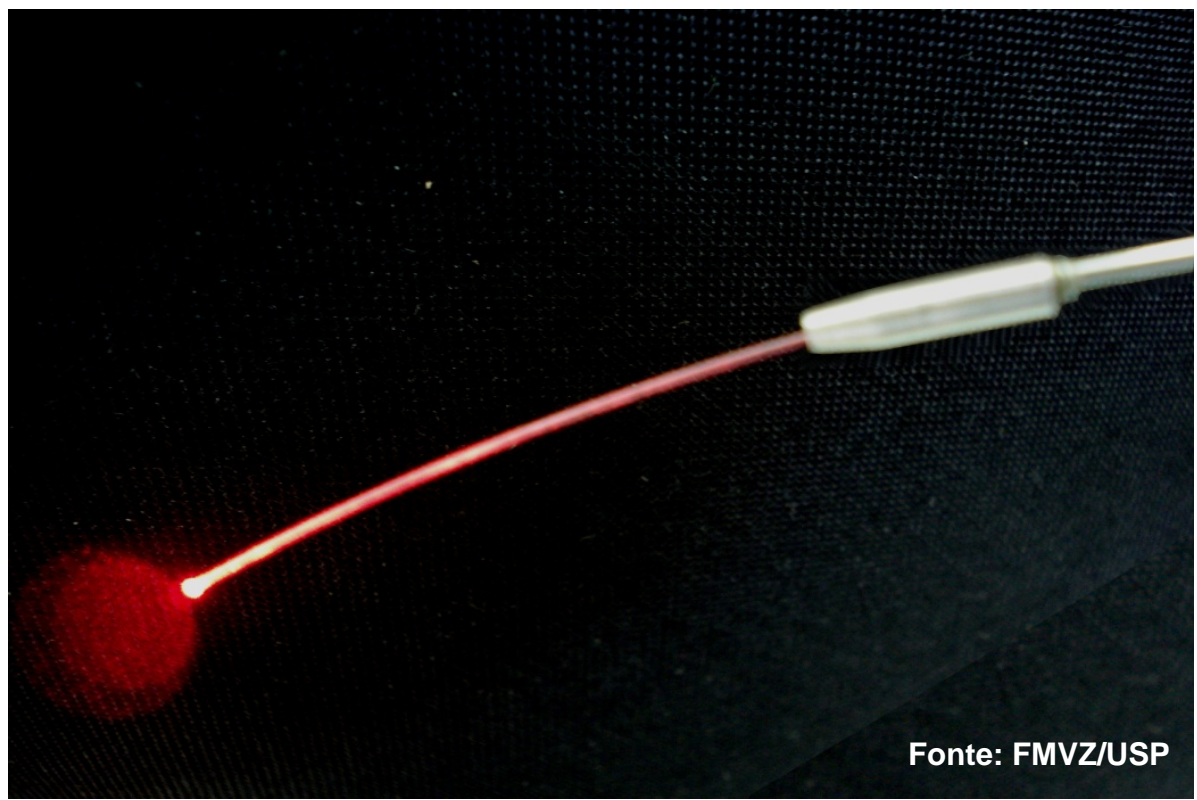

Figura 4 - Aspecto da fibra-óptica, acoplada à ponteira de aplicação, desenvolvido pela empresa Kroman (São Paulo, Brasil) especialmente para o uso em canais radiculares de cães, devido à sua grande extensão, quando comparado ao dente humano

\subsection{Fotossensibilizante (azuleno)}

O corante azuleno é um corante natural, extraído da camomila (Chamomilla recutita), utilizado em xampus e loções cosméticas. É formado por anéis aromáticos heterocíclicos sendo sua fórmula química 7-etil-1,4 dimetilazuleno. Sua estrutura química confere propriedade de absorção próxima ao comprimento de onda do laser GaAlAs utilizado neste estudo $(\lambda=670 \mathrm{~nm})$. Em alta concentração, o azuleno aplicado intracanalmente provoca manchamento da dentina, com difícil remoção após cinco minutos de tempo de pré-irradiação. Foi utilizado o corante a $25 \%$ associado ao Endo-PTC. O Endo-PTC é uma associação de fármacos utilizada em endodontia como substância química auxiliar. Segundo Paiva e Antoniazzi (1973), é composto de peróxido de uréia (10\%), tween80 (15\%) e carbowax (75\%). Quando associado ao hipoclorito de sódio, o Endo-PTC é um potente agente oxidante e antimicrobiano. Segundo Garcez et al. (2006) a associação do azuleno $25 \%$ ao 
endo-ptc é facilmente removida do canal por irrigação com solução salina ou água (remoção mecânica) ou hipoclorito de sódio a 0,5\%.

\subsection{Técnica Operatória e Coleta Microbiológica}

Os pacientes receberam medicação pré-anestésica, com uso de meperidina e acepromazina, e foram submetidos à anestesia geral inalatória com isoflurano em circuito semi-fechado, para que então se iniciasse o procedimento. Primeiramente foi realizada a anti-sepsia da cavidade oral com solução oral de gluconato de clorexidina a $0,12 \%$ seguida do isolamento do dente destinado ao procedimento cirúrgico. Após o isolamento do campo operatório com dique de borracha foi realizada raspagem dental para remoção de cálculo supra-gengival. O campo operatório e a superfície dental foram novamente descontaminados, utilizando-se o protocolo de Möller (1966), através da aplicação sucessiva de três soluções, com emprego de algodão e pinça estéreis, em um intervalo de tempo igual a 1 minuto: $1^{a}$ ) solução de peróxido de hidrogênio a $30 \%, 2^{\underline{a}}$ ) tintura de iodo a $10 \%, 3^{\underline{a}}$ ) tiossulfato de sódio a $5 \%$ para inativação do iodo, a fim de que este não influenciasse o resultado da amostra microbiológica posterior (Fig. 5). 


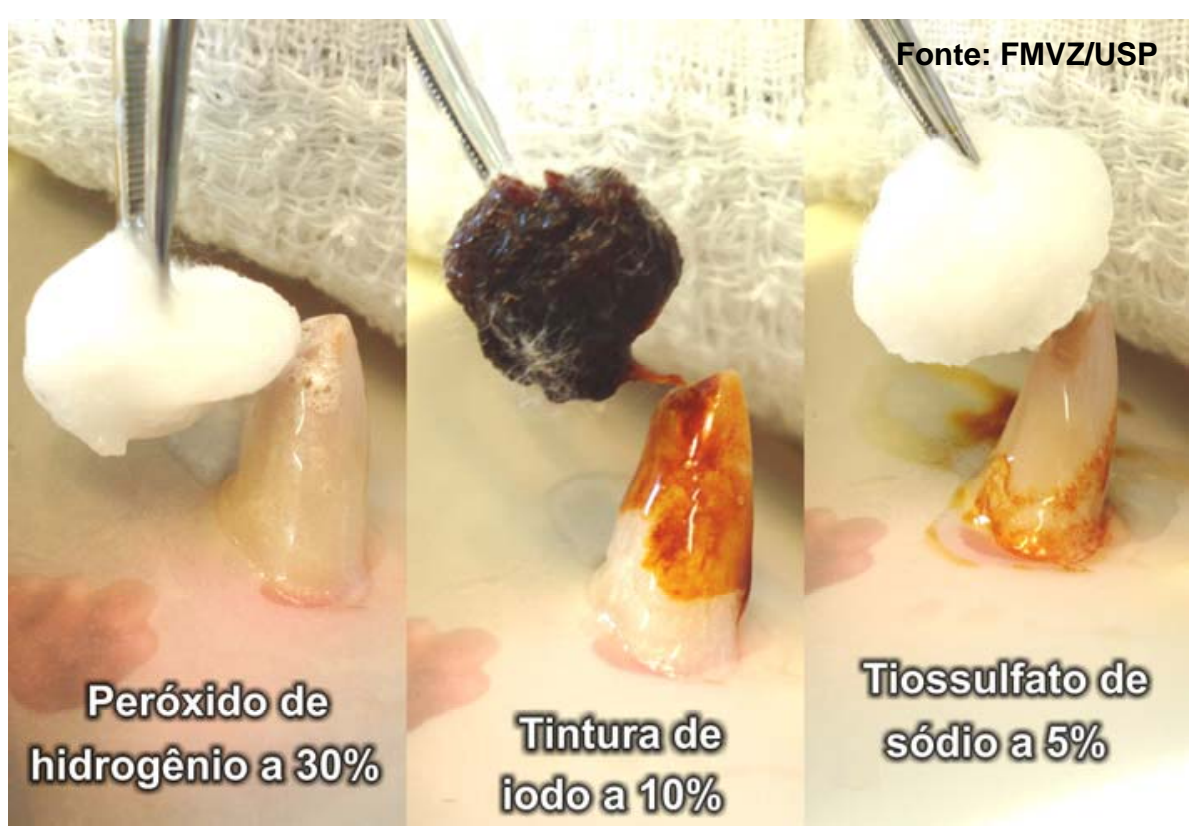

Figura 5 - Aplicação do protocolo proposto por Möller (1966) para antisepsia da superfície dentária. Ambas as substâncias foram aplicadas com emprego de algodão e pinça clínica estéreis e dique de borracha, para completo isolamento do elemento dentário

4.4.1 Avaliação da microbiota do canal radicular contaminado

Para avaliar a esterilidade da superfície coronária a fim de se verificar a esterilidade ao acesso à cavidade pulpar, utilizou-se uma bolinha de algodão esterilizada que foi passada sobre a coroa, logo após a aplicação do protocolo de Möller (1966). Esse material foi transferido para o meio de transporte pré-reduzido VMGA III (Viability Medium Goteborg Anaerobically) contendo pérolas de vidro de, aproximadamente, $5 \mathrm{~mm}$ de diâmetro para facilitar a mistura e homogeneização da amostra antes do cultivo.

Os vinte dentes estudados apresentavam fratura com exposição de canal radicular. Uma ponta diamantada esférica de tamanho compatível com o volume da 
câmara pulpar, avaliado pela radiografia inicial, em alta rotação sob refrigeração de água destilada, foi empregada para ampliar o sítio de acesso ao sistema de canais radiculares.

Imediatamente após o acesso, as amostras foram colhidas do interior do canal radicular ( $1^{\text {a }}$ coleta) com pinça clínica esterilizada e sem uso anterior, empregando-se três cones de papel esterilizados, os quais foram mantidos no interior do canal radicular durante 60 segundos (LE GOFF et al., 1997). Essa coleta teve como objetivo traçar a microbiota inicial nos casos de infecção endodôntica de caráter primário.

Caso nenhum exsudado fosse verificado nas pontas de papel absorvente, ao exame visual direto, o canal radicular era preenchido com solução fisiológica e, em seguida, nova coleta era feita, como descrito acima. Após a permanência dos cones de papel esterilizados no interior do canal radicular, por um intervalo de 60 segundos, estes foram imediatamente transferidos para frascos contendo $2 \mathrm{ml}$ de meio de transporte pré-reduzido VMGA III com pérolas de vidro.

\subsubsection{Divisão dos grupos}

Os vinte animais foram divididos em dois grupos de dez animais, de forma aleatória, sendo apenas um dente de cada indivíduo utilizado neste estudo (Apêndices $C$ e D). $O$ grupo I teve por objetivo avaliar a ação fotodinâmica do azuleno após o preparo químico-cirúrgico convencional, e o grupo II, avaliação da ação anti-microbiana do azuleno antes do preparo químico-cirúrgico convencional. 
4.4.2.1 Grupo I (preparo químico-cirúrgico convencional antes da terapia fotodinâmica)

Imediatamente após a cirurgia de acesso, o canal foi irrigado com $30 \mathrm{ml}$ de solução fisiológica com a finalidade de remover resíduos orgânicos ou químicos existentes e, então foi realizado o preparo químico-cirúrgico, empregando hipoclorito de sódio a $0,5 \%$ e endo-ptc, substâncias químicas preconizadas por Paiva e Antoniazzi (1973). O canal foi novamente irrigado com $30 \mathrm{ml}$ e, feito isso, nova coleta ( $2^{\underline{a}}$ coleta) foi realizada, como descrito anteriormente (Fig. 9). A $3^{\underline{a}}$ coleta teve como objetivo avaliar a ação antimicrobiana proporcionada pela fase de preparo do canal radicular.

Após este procedimento, foi feita a colocação da pasta de azuleno $25 \%$ no interior do canal radicular (Fig. 6). O corante permaneceu por 5 minutos e, em seguida, foi feita a aplicação do laser GaAlAs, de baixa potência (modelo KO 650 Kroman), sob $\lambda=670 \mathrm{~nm}, \mathrm{P}=50 \mathrm{~mW}, \mathrm{E}=4$ joules $/ \mathrm{cm} 2$, durante 3 minutos, de acordo com o protocolo de Garcez et al. (2006), através de fibra-óptica acoplada à ponteira laser, em movimentos helicoidais em direção ápico-cervical, para que a luz pudesse ser irradiada em toda a extensão do conduto (Fig. 7).

Quando do término da terapia fotodinâmica, o canal foi irrigado com $30 \mathrm{ml}$ de solução fisiológica e a $3^{\text {a }}$ coleta microbiológica foi realizada, como descrita anteriormente (Figs. 8 e 9). Esta visava avaliar a ação antimicrobiana proporcionada pelo emprego da terapia fotodinâmica com o corante azuleno irradiado por laser de baixa intensidade. 


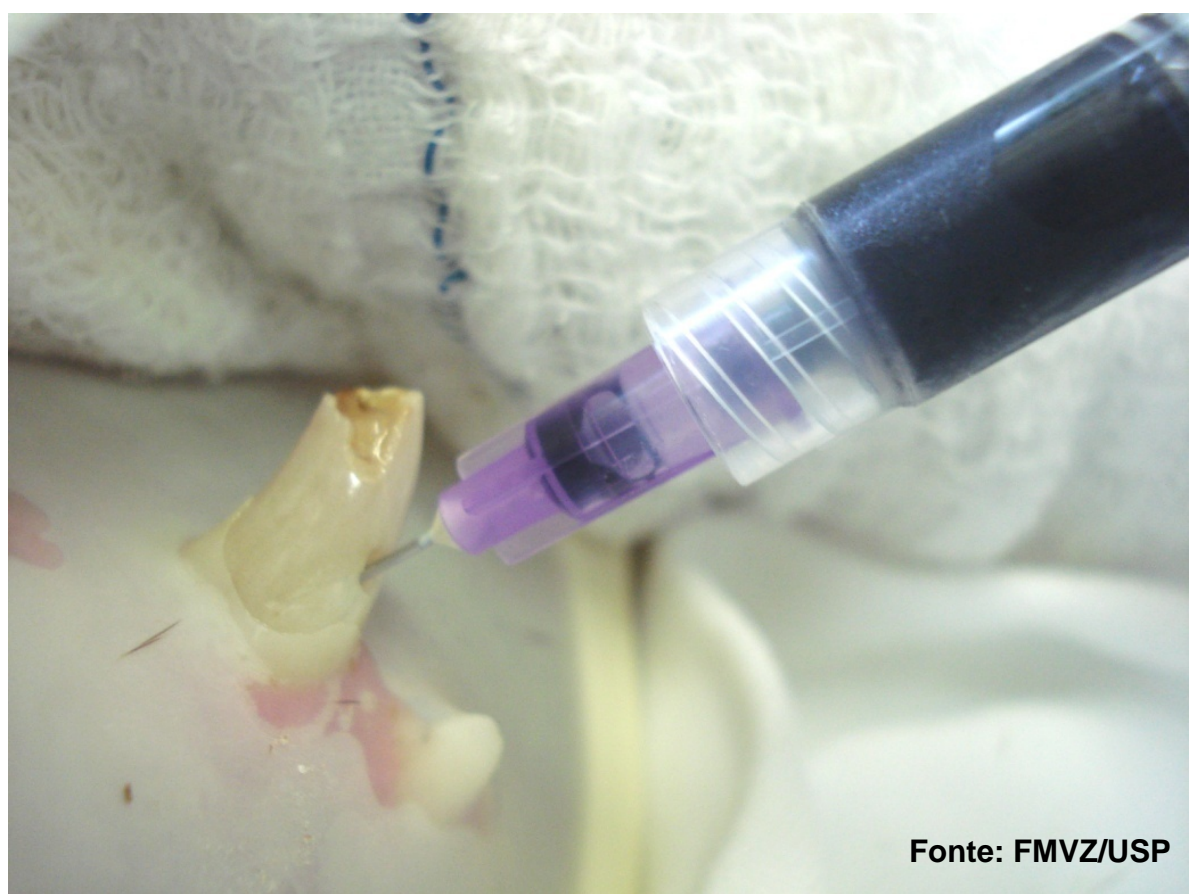

Figura 6 - Aplicação do corante azuleno, com emprego de seringa e agulha hipodérmica, no interior do canal radicular de um dente canino inferior direito de cão

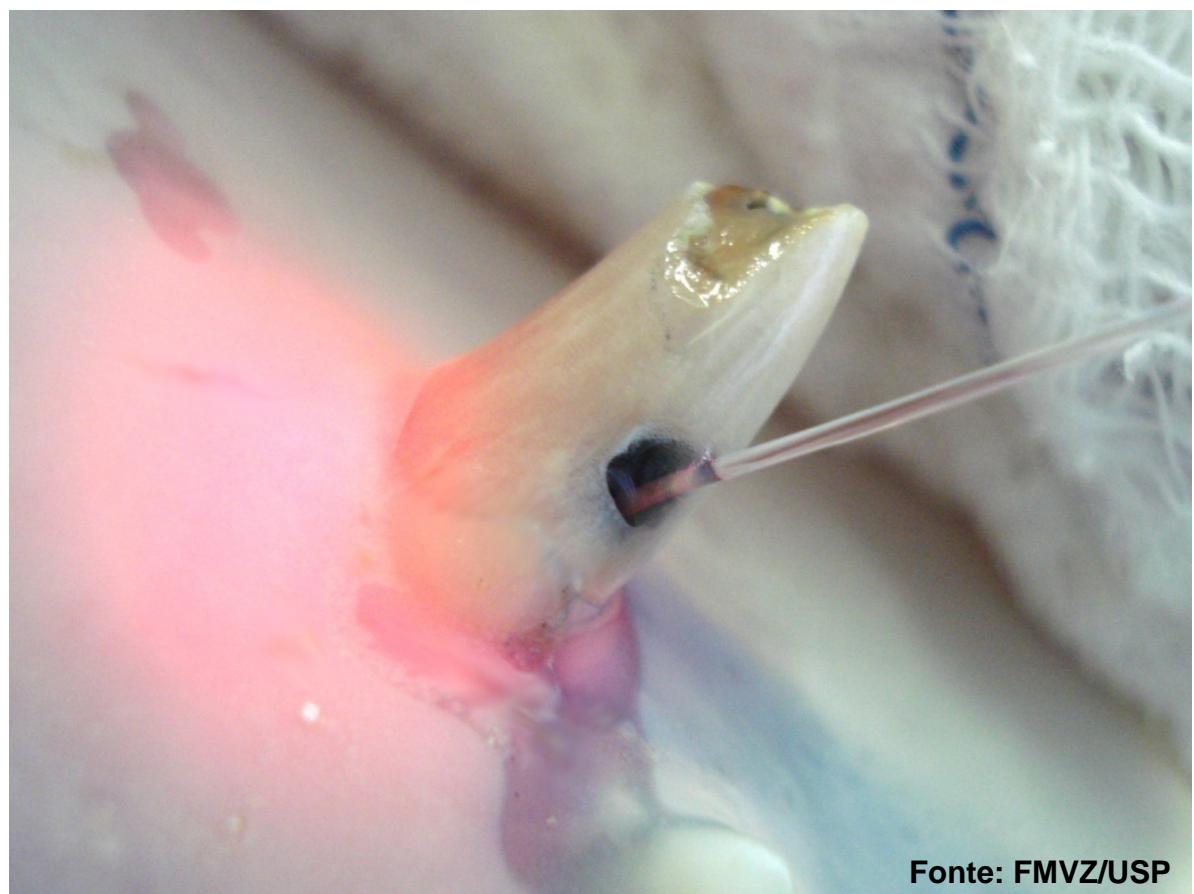

Figura 7 - Emprego de fibra-óptica no interior do canal radicular de dente canino inferior direito de um cão, para completa entrega da luz laser em toda a extensão do conduto, a fim de ativar o corante azuleno presente neste espaço 


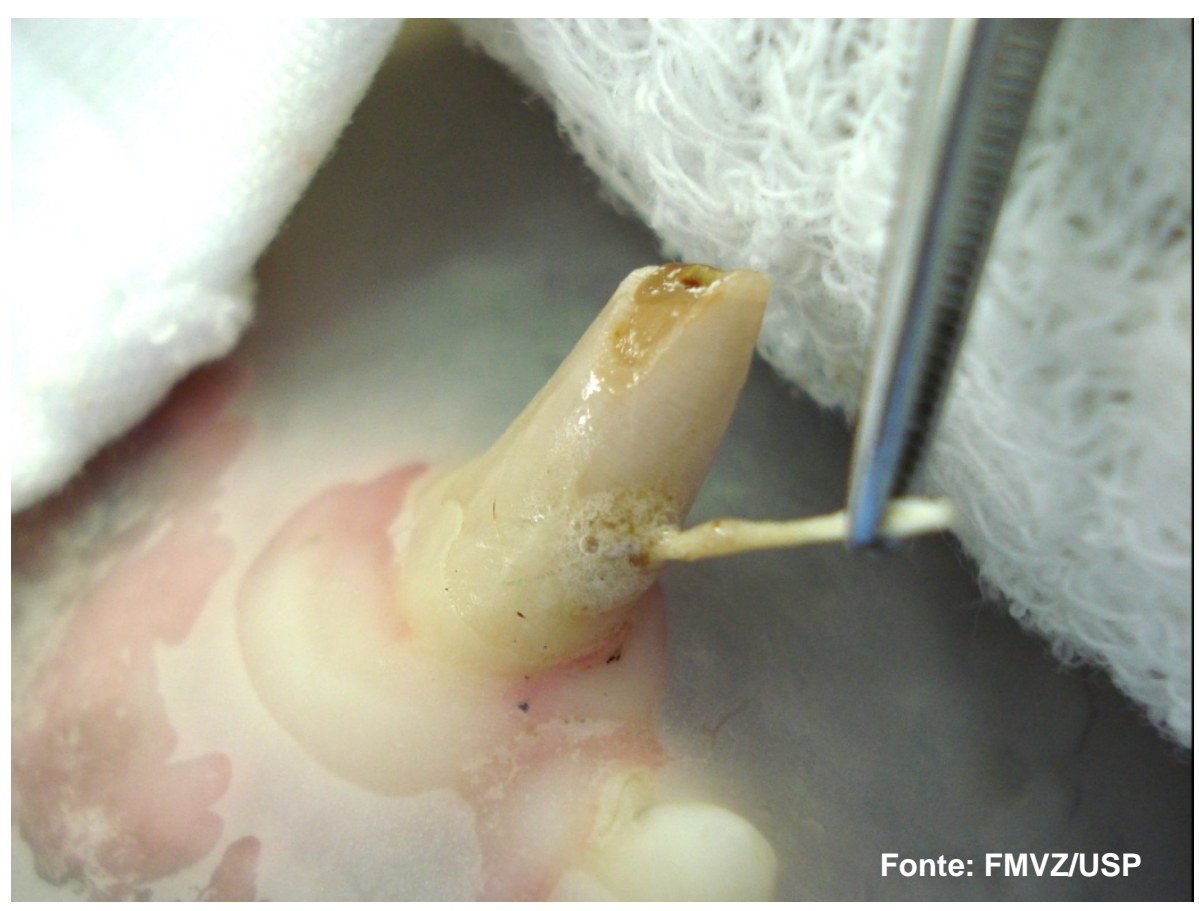

Figura 8 - Coleta microbiológica realizada com emprego de cone-de-papel estéril, introduzido com auxílio de uma pinça clínica odontológica, no interior do canal radicular de dente canino inferior direito de cão

\subsubsection{Grupo II (terapia fotodinâmica antes do preparo químico-cirúrgico convencional)}

Imediatamente após a cirurgia de acesso, o canal foi irrigado com $30 \mathrm{ml}$ de solução fisiológica com a finalidade de remover resíduos orgânicos ou químicos existentes. Após este procedimento, foi feita a colocação da pasta de azuleno $25 \%$ no interior do canal radicular. $O$ corante permaneceu por 5 minutos e, em seguida, foi aplicado o laser GaAlAs, de baixa potência (modelo KO 650 Kroman), sob $\lambda=$ $670 \mathrm{~nm}, \mathrm{P}=50 \mathrm{~mW}, \mathrm{E}=4$ joules $/ \mathrm{cm} 2$, durante 3 minutos, de acordo com o protocolo de Garcez et al. (2006), através de fibra-óptica acoplada à ponteira laser, em movimentos helicoidais em direção ápico-cervical, para que a luz pudesse ser irradiada em toda a extensão do conduto. 
Quando do término da terapia fotodinâmica, o canal foi irrigado com $30 \mathrm{ml}$ de solução fisiológica e a $2^{\text {a }}$ coleta microbiológica foi realizada, como descrita anteriormente (Fig. 9). Esta visava avaliar a ação antimicrobiana proporcionada pelo emprego da terapia fotodinâmica com o corante azuleno irradiado por laser de baixa intensidade.

O canal foi novamente irrigado com $30 \mathrm{ml} \mathrm{e}$, feito isso, foi realizado o preparo químico-cirúrgico, empregando hipoclorito de sódio a 0,5\% e endo-ptc, substâncias

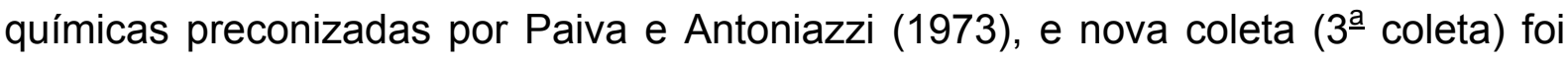
realizada, como descrito anteriormente (Fig. 9). A $3^{\text {a }}$ coleta teve como objetivo avaliar a ação antimicrobiana proporcionada pela fase de preparo do canal radicular.

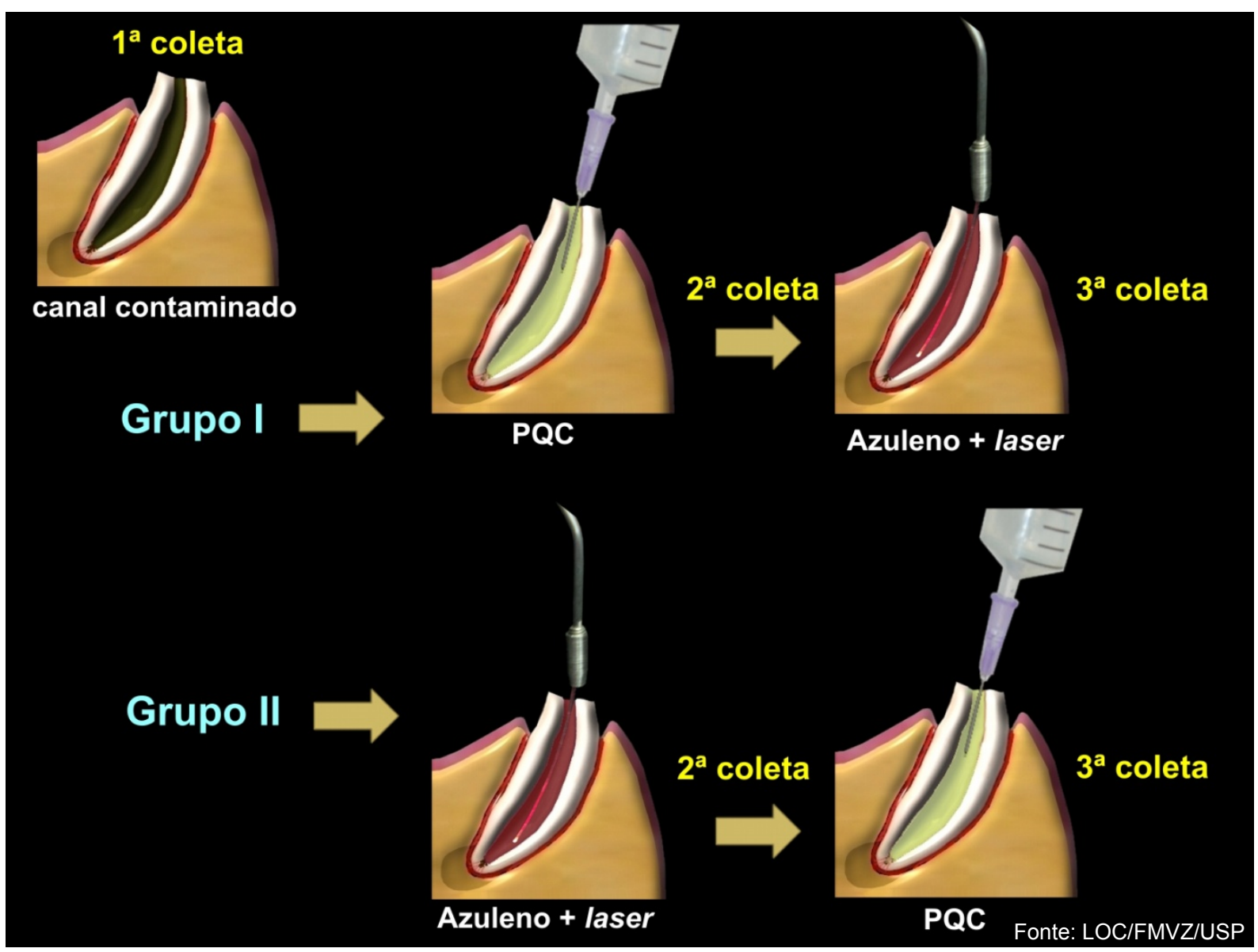

Figura 9 - Esquema representando os três momentos da coleta microbiológica com emprego de cones-de-papel estéril, nos dois grupos estudados, que diferiam no protocolo de antisepsia quanto ao momento de aplicação do PQC e PDT 


\subsection{Análise do material coletado}

Após realizada as três coletas, os meios de transporte pré-reduzidos VMGA III foram levados ao Laboratório de Microbiologia Oral do Departamento de Microbiologia do Instituto de Ciências Biomédicas da Universidade de São Paulo.

Cada tubo contendo as amostras era identificado com etiqueta constando nome, elemento dentário, data e número da coleta.

\subsubsection{Isolamento dos Microrganismos}

As amostras foram encaminhadas ao Laboratório em um período máximo de 6 horas após a coleta. Inicialmente, os frascos contendo as amostras em VMGA III foram mantidos em estufa microbiológica a $37{ }^{\circ} \mathrm{C}$ por um período de aproximadamente 30 minutos objetivando a liquefação da gelatina do meio.

Posteriormente as amostras foram dispersas vigorosamente em agitador mecânico por 15 segundos e diluídas a 1/10, 1/100 e 1/1000 em água peptonada, no interior da câmara de fluxo laminar.

Alíquotas de $25 \mu \mathrm{l}$ da amostra sem diluição e das amostras diluídas a 1/10, $1 / 100$ e 1/1000 foram semeadas, em triplicata, na superfície de placas do tipo Petri contendo os seguintes meios de cultura:

- ágar m-Enterococcus: seletivo para detecção de espécies de enterococos.

- ágar Sabouraud-dextrose acrescido de 0,1\% cloranfenicol: seletivo para detecção de espécies de leveduras. 
- ágar Brucella acrescido de solução de hemina (10 $\mu \mathrm{g} / \mathrm{ml})$, menadione (1 $\mu \mathrm{g} / \mathrm{ml}$ ), e sangue desfibrinado de carneiro $5 \%$ : para crescimento de bactérias totais (Fig. 10).

A seguir, as placas de ágar m-Enterococcus foram incubadas a $37{ }^{\circ} \mathrm{C}$ por período de 24 a 48 horas e as placas de ágar Sabouraud-dextrose durante quatro dias à temperatura ambiente. As placas de ágar Brucella sangue foram incubadas a $37^{\circ} \mathrm{C}$, sob anaeróbiose, por um período de quatro dias (Fig. 10).

Passados estes períodos, as placas que apresentaram crescimento microbiano foram analisadas através de microscópio estereoscópico para caracterização morfológica das unidades formadoras de colônia (u.f.c.).

Nas amostras semeadas em placas com meios seletivos m-Enterococcus e Sabouraud-dextrose onde ocorreu crescimento bacteriano, foi realizada a coloração de Gram, com a finalidade de identificação presuntiva das colônias.

O crescimento observado nas placas de ágar Brucella sangue foi analisado em microscópio estereoscópico, não sendo submetido a nenhum teste específico. 


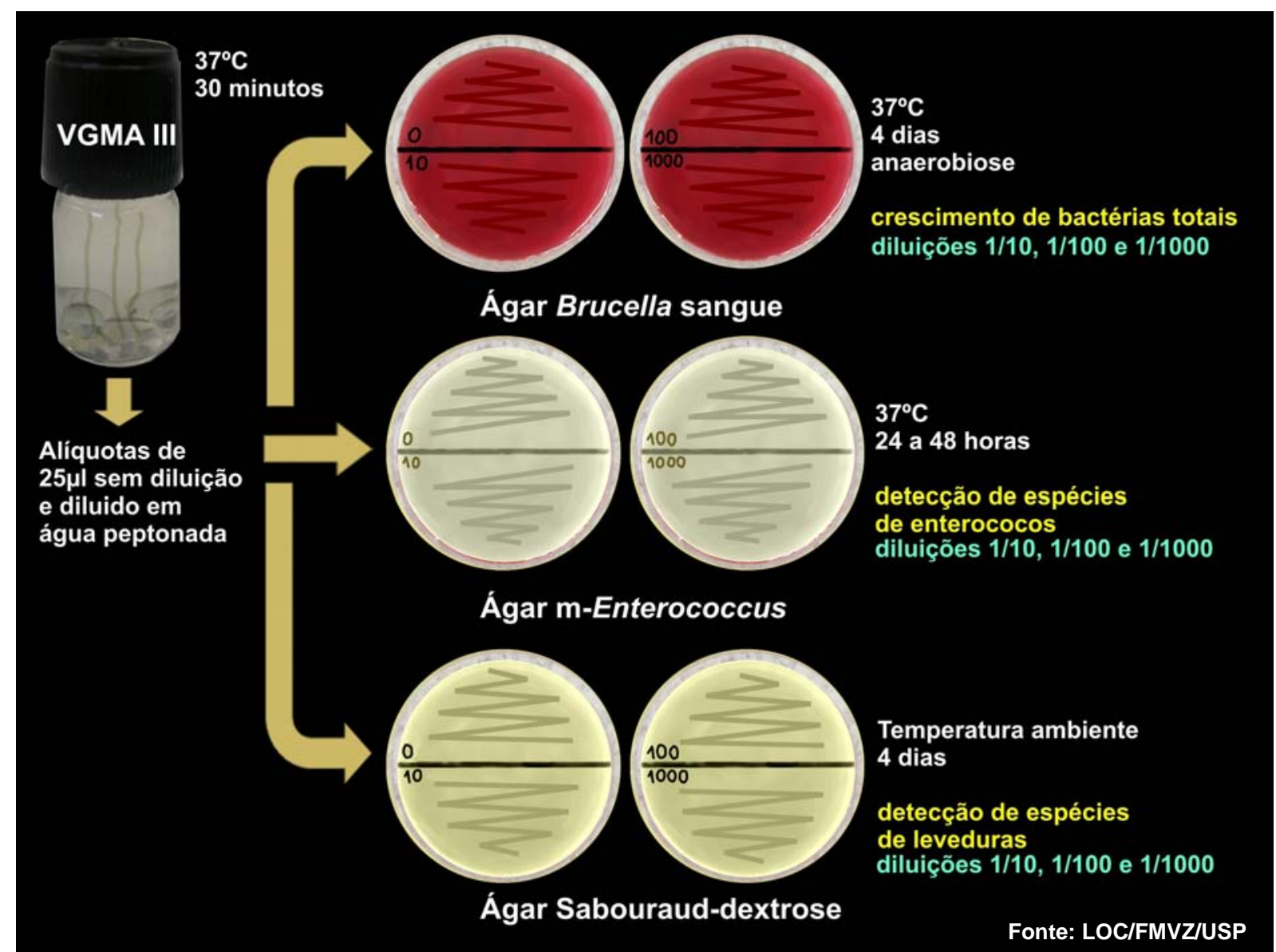

Figura 10- Esquema de isolamento dos microorganismos a partir do meio de transporte VGMA III, contendo os cones-de-papel utilizados durante a coleta intracanal, em três meios de cultura (em diferentes diluições) para determinação de UFC para bactérias totais, espécies de enterococos e espécies de leveduras. Cada placa foi semeada em triplicata, em seguida, incubada em tempo e temperatura específica. 


\subsection{Obturação e restauração}

Ao término do esvaziamento e anti-sepsia dos canais radiculares, tanto no grupo I como II, prosseguiu-se com a obturação. O canal foi preenchido com uso de cimento endodôntico a base de óxido de zinco e eugenol e selado com introdução de cones de gutta-percha. Todos os dentes foram restaurados com uso de resina composta fotopolimerizável (bisfenol-A-glicildimetacrilato).

\subsection{Análise estatística}

Foram avaliadas as unidades formadoras de colônias (UFCs) em cada uma das diluições, sendo atribuído a cada animal o título (última diluição com UFC). As análises subseqüentes foram feitas com base neste parâmetro.

Para a comparação dos títulos entre as coletas, estratificando-as pelos meios e grupos, foi realizado o teste não-paramétrico de Friedman (indicado para a comparação de $k$ grupos dependentes). Nos casos onde foram detectadas diferenças significativas $(p<0,05)$, aplicou-se o teste não-paramétrico de Wilcoxon (indicado para a comparação de dois grupos dependentes), buscando-se verificar as diferenças entre as coletas, duas a duas.

Para a comparação dos títulos entre os grupos, estratificando-os pelos meios e coletas, foi utilizado o teste não-paramétrico de Mann-Whitney (indicado para a comparação de dois grupos independentes), também considerando $p<0,05$.

Para a realização das comparações, foi utilizado o programa de computador SPSS 9.0 . 
5

RESULTADOS

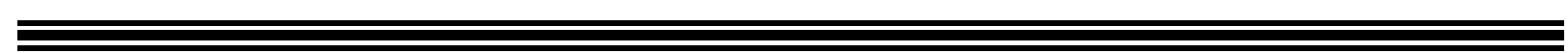




\section{RESULTADOS}

Para o entendimento das avaliações de anti-sepsia, tanto pelo PQC como pelo PDT, foram considerados os resultados da última diluição que apresentasse UFC (Apêndices A e B).

\subsection{Grupo I}

$\mathrm{Na}$ primeira coleta de material intracanal, nove dentes (90\%) apresentaram contaminação bacteriana, encontrando-se espécies de enterococos em sete dentes (70\%) e presença de espécies de leveduras em três dentes (30\%) (Tabela 1).

Tabela 1 - Número de dentes do grupo I que apresentaram algum tipo de microorganismo nas três etapas de avaliação microbiológica, antes da anti-sepsia, após o preparo químico-cirúrgico e após a terapia fotodinâmica $(n=10)$

\begin{tabular}{cccc}
\hline Contaminação & $\begin{array}{c}1^{\mathrm{a}} \text { COLETA } \\
\text { acesso ao canal } \\
\text { (dentes) }\end{array}$ & $\begin{array}{c}\mathbf{2}^{\mathrm{a}} \text { COLETA } \\
\text { após PQC } \\
\text { (dentes) }\end{array}$ & $\begin{array}{c}3^{\mathrm{a}} \text { COLETA } \\
\text { após PDT } \\
\text { (dentes) }\end{array}$ \\
\hline Bactérias totais & 10 & 3 & 1 \\
Espécies de enterococos & 10 & 5 & 0 \\
Espécies de leveduras & 3 & 0 & 0 \\
\hline
\end{tabular}


$\mathrm{Na}$ segunda coleta de material intracanal, após a anti-sepsia pelo PQC (hipoclorito de sódio a 0,5\% e endo-ptc), houve redução de 100\% de bactérias totais em sete dentes $(77,7 \%)$ dos nove contaminados; redução de $100 \%$ de espécies de enterococos em cinco dentes $(71,4 \%)$ dos sete contaminados e redução de $100 \%$ de espécies de leveduras nos três dentes $(100 \%)$ contaminados (Tabela 1$)$.

$\mathrm{Na}$ terceira coleta de material, após a desinfecção pelo PDT (pasta de azuleno e endo-ptc irradiado por laser), houve redução de $100 \%$ de bactérias totais em dois $(66,6 \%)$ dos três dentes que ainda apresentavam contaminação; redução de $100 \%$ de espécies de enterococos nos dois dentes (100\%) que ainda apresentavam contaminação (Tabela 1).

A eficácia do PDT não pôde ser avaliada na redução de leveduras, pois todas as amostras com esta contaminação já haviam sido reduzidas em $100 \%$ apenas com o PQC (Apêndice A).

\subsection{Grupo II}

$\mathrm{Na}$ primeira coleta de material intracanal, dez dentes (100\%) apresentaram contaminação bacteriana, encontrando-se espécies de enterococos nos dez $(100 \%)$ dentes. A presença de espécies de leveduras foi constatada em 4 dentes $(40 \%)$ (Tabela 2).

$\mathrm{Na}$ segunda coleta de material intracanal, após a desinfecção pelo PDT (pasta de azuleno e endo-ptc irradiado por laser), houve redução de $100 \%$ de bactérias totais em nove $(90 \%)$ dos dez dentes que apresentaram contaminação; redução de $100 \%$ de espécies de enterococos nos dez dentes (100\%) que apresentaram contaminação e redução de $100 \%$ de espécies de leveduras em todos os quatro dentes (100\%) que apresentaram esta contaminação (Tabela 2). 
$\mathrm{Na}$ terceira coleta de material, após a desinfecção pelo PQC convencional (hipoclorito de sódio a 0,5\% e endo-ptc), houve redução de $100 \%$ de bactérias totais no único dente $(100 \%)$ em que se constatou a persistência desta contaminação; tanto para espécies de enterococos como para de leveduras (Tabela 2).

Tabela 2 - Número de dentes do grupo II que apresentaram algum tipo de microorganismo nas três etapas de avaliação microbiológica, antes da anti-sepsia, após o preparo químico-cirúrgico e após a terapia fotodinâmica $(n=10)$

\begin{tabular}{cccc}
\hline Contaminação & $\begin{array}{c}1^{\text {a }} \text { COLETA } \\
\text { acesso ao canal } \\
\text { (dentes) }\end{array}$ & $\begin{array}{c}2^{\text {a }} \text { COLETA } \\
\text { após PDT } \\
\text { (dentes) }\end{array}$ & $\begin{array}{c}3^{\text {a COLETA }} \\
\text { após PQC } \\
\text { (dentes) }\end{array}$ \\
\hline Bactérias totais & 10 & 1 & 0 \\
Espécies de enterococos & 10 & 0 & 0 \\
Espécies de leveduras & 4 & 0 & 0 \\
\hline
\end{tabular}

A eficácia do PQC também não pôde ser avaliada na redução de espécies de enterococos e leveduras, pois todas as amostras com esta contaminação já haviam sido reduzidas em $100 \%$ apenas com o PDT (Apêndice B).

\subsection{Avaliação estatística}

As análises estatísticas foram realizadas comparando-se os títulos entre as coletas (Tabela 3) utilizando o teste não-paramétrico de Friedman. Como houve diferença significativa entre as diluições $(p<0,05)$, aplicou-se o teste não paramétrico de Wilcoxon. 
Tabela 3 - Comparação dos títulos entre as coletas, estratificada pelos protocolos e meios de cultura

\begin{tabular}{|c|c|c|c|c|c|}
\hline \multirow[t]{2}{*}{ Protocolo } & \multirow[t]{2}{*}{ Meio } & \multirow{2}{*}{$\begin{array}{l}\text { Teste de Friedman } \\
\text { (p) }\end{array}$} & \multicolumn{3}{|c|}{ Teste de Wilcoxon (p) } \\
\hline & & & Coleta $1 \times 2$ & Coleta $1 \times 3$ & Coleta $2 \times 3$ \\
\hline \multirow{3}{*}{ Grupo I } & BRU & $<0,001^{*}$ & $0,011^{* *}$ & $0,007^{* * *}$ & 0,320 \\
\hline & m-Ent & $<0,001^{*}$ & $0,014^{* *}$ & $0,014^{* * *}$ & 1 \\
\hline & Sab & $0,050^{*}$ & 0,100 & 0,100 & 1 \\
\hline \multirow{3}{*}{ Grupo II } & BRU & $<0,001^{*}$ & $0,004^{* *}$ & $0,004^{* * *}$ & 1 \\
\hline & m-Ent & $<0,001^{*}$ & $0,002^{* *}$ & $0,002^{* * *}$ & 1 \\
\hline & Sab & $0,018^{*}$ & 0,059 & 0,059 & 1 \\
\hline \multicolumn{6}{|c|}{ * Diferenças significativas dos títulos entre as coletas } \\
\hline \multicolumn{6}{|c|}{ ** Diferença significativa dos títulos entre as coletas $(1>2)$} \\
\hline \multicolumn{6}{|c|}{${ }^{* * *}$ Diferença significativa dos títulos entre as coletas $(1>3)$} \\
\hline
\end{tabular}

Os títulos obtidos nos dois protocolos utilizados foram comparados através do teste paramétrico de Mann-Whitney (Tabela 4). O resultado desta avaliação não mostrou diferença significativa $(p<0,05)$ entre os dois protocolos de anti-sepsia aplicados em cada um dos grupos avaliados.

Tabela 4 - Comparação dos títulos entre os protocolos, estratificada pelos meios de cultura e coletas

\begin{tabular}{ccc}
\hline Meio & Coleta & Teste de Mann-Whitney $(\mathbf{p})$ \\
\hline \multirow{2}{*}{ BRU } & $1^{\text {a }}$ coleta & 0,85 \\
& $2^{\text {a }}$ coleta & 0,74 \\
& $3^{\text {a coleta }}$ & 0,74 \\
& $1^{\text {a }}$ coleta & 0,11 \\
m-Ent & $2^{\text {a coleta }}$ & 1 \\
& $3^{\text {a coleta }}$ & 1 \\
& $1^{\text {a coleta }}$ & 0,85 \\
Sab & $2^{\text {a coleta }}$ & 1 \\
& $3^{\text {a coleta }}$ & 1 \\
\hline
\end{tabular}

sd = sem diluição; bru = Agar Brucella; m-Ent = Ágar m-Enterococcus; Sab = Ágar Sabourauddextrose 
6

DISCUSSÃO

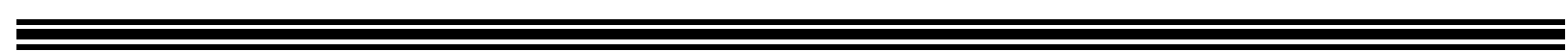




\section{DISCUSSÃO}

Segundo Venceslau e Gioso (2000), 24,30\% dos animais anestesiados no Hospital Veterinário da FMVZ/USP apresentavam traumas dentários. Apesar desta elevada casuística no mesmo serviço de atendimento, apenas os vinte pacientes estudados atendiam ao critério de seleção proposto por este estudo.

O critério de seleção seguiu o proposto por Ferrari et al. (2005), que visou determinar o grau de contaminação pelos mesmos grupos de microorganismos que foram estudados neste experimento, ou seja, bactérias totais, espécies de enterococos e espécies de leveduras.

Baseado no critério de seleção dos dentes, todos os vinte animais estudados apresentavam, radiograficamente, presença de rarefação óssea periapical. Esta escolha foi baseada na afirmação de Sundqvist (1976), cujo experimento demonstrou que a presença de bactérias tem relação com a lesão periapical. Apesar da radiografia intra-oral ser um importante instrumento para avaliação do processo de cura da lesão peri-apical, este projeto não incluiu a realização de radiografias de acompanhamento pois os animais estudados eram provenientes da casuística do Hospital Veterinário da FMVZ/USP, existindo o risco de que nem todos os proprietários de animais colaborassem.

Kawamoto (2000) afirmou que foram estudados diversos corantes, sob ativação de luz, para eliminação de microorganismos. Seguindo a linha de pesquisa de Hayek et al. (2005) e Garcez et al. (2006), foi escolhido o corante azuleno para o presente estudo.

Akpata e Blechman (1982) afirmam que, em dentes humanos, quanto maior o tempo de exposição, maior a invasão intracanal por Enterococcus faecalis. Desta forma, apesar de não identificar a espécie, foi escolhido avaliar espécies de enterococos. Na contagem de unidades formadoras de colônia, $100 \%$ dos dentes estudados apresentaram tal contaminação. 
Ayhan et al. (1999) testaram várias substâncias utilizadas durante a antisepsia dos canais radiculares humanos contra diversos agentes patógenos, incluindo a levedura Candida albicans. Pinheiro et al. (2003) também encontraram a mesma espécie de levedura em dentes humanos que apresentavam falha no tratamento de canal. Radcliffe et al. (2004) determinaram a resistência da Candida albicans ao emprego do hipoclorito de sódio em diferentes concentrações. Apesar de não ter sido identificado em gênero e espécie, a contagem de unidades formadoras de colônias para espécies de leveduras justificou-se no presente estudo, tendo sido encontrada em $35 \%$ dos dentes estudados.

Durante o desenvolvimento deste experimento, houve algumas dificuldades, posteriormente superadas, na avaliação microbiológica. No início do experimento, antes dos vinte dentes selecionados para a avaliação, outros quatro cães, obedecendo ao critério de seleção, foram submetidos às coletas. Porém, devido à falta de experiência na coleta microbiológica, ocorreram as seguintes falhas: inativação dos meios de transporte (VGMA III) por contaminação por oxigênio do ar ambiente e contaminação das amostras durante a semeadura das placas. A inclusão dos dados destas coletas afetaria o resultado e a avaliação da eficácia dos métodos de anti-sepsia. Tais dados foram descartados.

Vários experimentos, em odontologia humana, propõem 0 uso de fotossensibilizantes no processo de saneamento do sistema de canais radiculares (SEAL et al., 2002), com diversos corantes e fontes de luz, porém testando sua eficácia isolada, e não como parte do protocolo de anti-sepsia empregada na rotina clínica.

A importância de realizar um estudo envolvendo as duas formas de antisepsia é valorizar uma das propriedades do hipoclorito de sódio que é a solubilização de proteínas (SPANO, 1999), propriedade que os corantes não apresentam. Daí a importância de avaliar os resultados envolvendo os dois protocolos de anti-sepsia, em diferentes ordens de aplicação, para que o resultado justificasse seu uso em pacientes com lesão endodôntica e contaminação pulpar.

Desta forma, idealizou-se o projeto dividindo os vinte animais em dois grupos, diferindo no protocolo de anti-sepsia do canal radicular contaminado. No grupo I, foi aplicado o preparo químico-cirúrgico (PQC) utilizando hipoclorito de sódio a 0,5\% e 
endo-ptc e, posteriormente, a terapia fotodinâmica (PDT) utilizando o corante azuleno irradiado por laser de baixa intensidade. No grupo II, o protocolo de antisepsia foi invertido, iniciando pelo PDT seguido do PQC. Foram realizadas coletas microbiológicas do conteúdo do canal radicular em três momentos: após a cirurgia de acesso, e imediatamente antes de cada método de anti-sepsia. As coletas foram realizadas através de introdução de pontas-de-papel estéril, semelhante ao que foi descrito por Ferrari et al. (2005). A adaptação realizada neste estudo foi o emprego de pontas-de-papel de uso veterinário, uma vez que os condutos apresentam dimensões diferentes dos dentes humanos estudados por Ferrari et al. (2005).

Na avaliação estatística do grupo I, através do Teste de Friedman, pôde-se verificar que houve diferença significativa $(p<0,05)$ entre as culturas provenientes das três coletas, tanto para bactérias totais como para enterococos.

Ao comparar as placas da primeira com a segunda coleta, tanto para bactérias totais como espécies de enterococos, o Teste de Wilcoxon mostrou que houve diferença significativa na descontaminação realizada pelo PQC. Logo, podese afirmar que o hipoclorito de sódio, em conjunto com o endo-ptc, teve ação antimicrobiana, como afirmam Aynah et al. (1999), Önçağ et al. (2003), Menezes et al. (2004) e Radcliffe et al. (2004) em suas pesquisas realizadas em dentes humanos.

Não houve diferença significativa entre o título das culturas da segunda coleta e terceira. Possivelmente a descontaminação já havia sido realizada pelo PQC, logo, estatisticamente nada se pode afirmar sobre o PDT e sua eficácia na descontaminação do canal neste grupo. Todavia, ao analisar a tabela 1, o PDT diminuiu a contaminação bacteriana em $66,6 \%$ dos dentes em que ainda persistia contaminação por bactérias totais, mesmo após o PQC, sugerindo possível ação complementar no processo de anti-sepsia.

Ao comparar a primeira coleta com a terceira, o Teste de Wilcoxon apresentou diferença significativa. Apesar disto, mais uma vez não se pode afirmar que o PDT tenha sido eficaz na descontaminação dos dentes deste grupo, pois a anti-sepsia pode já ter ocorrido pelo PQC. 
$\mathrm{Na}$ avaliação estatística do grupo II, através do Teste de Friedman, pôde-se verificar que houve diferença significativa $(p<0,05)$ entre as culturas provenientes das três coletas, tanto para bactérias, espécies de enterococos e espécies de leveduras.

Ao comparar as placas da primeira com a segunda coleta, o Teste de Wilcoxon mostra que houve diferença significativa na descontaminação realizada pelo PDT, tanto para bactérias totais como para espécies de enterococos. A eficácia demonstrada na anti-sepsia dos canais radiculares corrobora com os resultados obtidos em pesquisas realizadas em dentes humanos por Seal et al. (2002), Garcez et al. (2006), Borsor et al. (2006) e Nikolaos et al. (2006).

Não houve diferença significativa entre o título das culturas da segunda coleta e terceira. Possivelmente a descontaminação já havia sido realizada pelo PDT, logo, estatisticamente nada se pode afirmar que $O P Q C$ e sua eficácia na descontaminação do canal neste grupo.

Ao comparar a primeira coleta com a terceira, o Teste de Wilcoxon apresentou diferença significativa. Apesar disto, mais uma vez não se pode afirmar que o PQC tenha sido eficaz na descontaminação dos dentes deste grupo, pois a anti-sepsia, neste grupo, pode já ter ocorrido pelo PDT.

No caso da cultura de leveduras do grupo I, o valor de $p(0,05)$ no teste de Friedman demonstra que há uma tendência em afirmar que houve diminuição do número de UFC nas placas após o PQC, porém, seria indicado aumentar o número de amostras com este microorganismo para poder alcançar um valor com significado estatístico. Já no grupo II, o Teste de Wilcoxon apresentou p próximo do significativo $(p<0,05)$, sugerindo que há uma tendência do PDT, aplicado diretamente no canal contaminado, em realizar a descontaminação destes microorganismos. Ao se verificar a ação do PQC sobre as leveduras, não houve diferença significativa com o resultado obtido pelo PDT. Na literatura pesquisada, não foram encontradas referências relatando a eficácia do uso da terapia fotodinâmica na redução de leveduras no interior do canal radicular de cães.

Segundo a tabela 4, ao comparar a ação do PQC e PDT na segunda e terceira coleta dos dois grupos, não houve diferença significativa $(p<0,05)$ entre 0 
resultado da anti-sepsia, o que sugere que o PQC e PDT, quando empregados de maneira independentemente da ordem de aplicação, apresentam ação antimicrobiana semelhantes.

Nos dois grupos estudados, o PDT foi executado aplicando-se no canal radicular o corante azuleno, mantido em repouso para, posteriormente, sofrer irradiação por laser de baixa intensidade durante três minutos. A luz laser foi aplicada com introdução de fibra-óptica, em movimentos helicoidais em sentido ápico-cervical. Em ambos os grupos, o PDT mostrou capacidade de anti-sepsia com este método de aplicação, que foi preconizado por Garcez et al. (2006). Para que fosse possível irradiar a luz laser em toda a extensão do conduto, foi necessário adquirir fibra-óptica de maior comprimento, devido às diferenças anatômicas entre o dente humano e canino.

Apesar da eficácia na desinfecção apresentada pelo fotossensibilizante azuleno, quando irradiado por laser de baixa intensidade, este método não substitui o emprego de hipoclorito de sódio, pois esta substância química auxiliar possui a propriedade de solubilização de proteínas (SPANO, 1999), muito importante no esvaziamento mecânico do canal radicular.

O emprego da terapia fotodinâmica, como método de anti-sepsia no tratamento endodôntico, ainda carece de novas pesquisas, tanto na odontologia humana como veterinária. Durante o levantamento bibliográfico, poucos foram os artigos encontrados sobre o tema, dificultando a discussão. 


\section{CONCLUSÕES}

Com base na metodologia empregada e nos resultados alcançados, pôde-se concluir que:

1. É possível empregar a terapia fotodinâmica com uso de laser de baixa potência e corante fotossensibilizante dentro da rotina odontoveterinária, nos casos de necropulpectomia, desde que utilizado o equipamento adequado, com fibra óptica longa para uso veterinário.

2. A terapia fotodinâmica intracanal tem eficácia semelhante à anti-sepsia clássica do preparo químico-cirúrgico.

3. A ordem de emprego do preparo químico-cirúrgico e terapia fotodinâmica não influencia no resultado da anti-sepsia.

4. O emprego de azuleno irradiado por laser de baixa potência tem grande eficácia sobre espécies de enterococos no interior dos condutos.

5. O emprego de azuleno irradiado por laser de baixa potência é eficaz na diminuição do número de bactérias totais intraradiculares.

6. Os resultados sugerem que o emprego de azuleno irradiado por laser possa diminuir a quantidade de espécies de leveduras, mas carece de novos experimentos com número maior de amostra.

7. Os aparelhos laser de uso humano devem ser adaptados para sua utilização em odontologia veterinária, devido às diferenças anatômicas. 
REFERÊNCIAS 


\section{REFERÊNCIAS}

ACKROYD, R.; KELTY, C.; BROWN, N.; REED, M. The history of photodetection and photodynamic therapy. Photochemistry and Photobiology, v. 74, p. 656-669, 2001.

AKPATA, E. S.; BLECHMAN, H. Bacterial invasion of pulpal dentin wall in vitro. Journal of Dental Research, v. 62, p. 435-438, 1982.

ANDO, N.; HOSHIRO, E. Predominant obligate anaerobes invading the deep layers of root canal dentine. International Endodontic Journal, v. 23, p. 20-27, 1990

AYHAN, H.; SULTAN, N.; CIRAK, M.; RUHI, M. Z.; BODUR, H. Antimicrobial effects of varius endodontic irrigants on selected microorganisms. International Endodontic Journal, v. 32, p. 99-102, 1999

BAUER, T. W.; HAHN, S. M.; SPITZ, F. R.; KACHUR, A.; GLATSTEIN, E.; FRAKER, D. L. Preliminary report of photodynamic therapy of intraperiotoneal sarcomatosis. Annals of Surgical Oncology, v. 8, p. 254-259, 2001.

BAUGH, C. L.; CLARK, J. B. Photodynamic response in bacteria. Journal of General Physiology, v. 42, p. 917-922, 1959.

BONSOR, S. J.; NICHOL, R.; REID, T. M. S.; PEARSON, G. J. Microbiological evaluation of photo-activated disinfection in endodontics (an in vivo study). British Dental Journal, v. 200, p. 337-341, 2006.

BRUGNERA J. R. A.; PINHEIRO, A. L. B. Lasers na odontologia. Ed.Pancast, São Paulo, 1998.

COHEN, S.; BURNS, R. C. Caminhos da Polpa, Saint Louis: Guanabara-Koogan, 7. e d. 1998,838 p. 
DAHLEN, G.; SAMUELSSON, W.; MOLANDER, A.; REIT, C. Identification and antimicrobial susceptibility of enterococci isolated from the root canal. Oral Microbiology Immunology, v. 15, p. 309-312, 2000

DOBSON, J.; WILSON, M. Sensitization of oral bacteria in biofilms to killing by light from a low-power laser. Archives of Oral Biology, v. 37, p. 883-887, 1992.

FABRICIUS, L.; DAHLEN, G.; HOLM, S.E.; MOLLER, A.J.R. Influence of combinations of oral bacteria on periapical tissues of monkeys. Scandinavian Journal of Dental Research, v.90, p.200-2006, 1982.

FERRARI, P.H. P.; CAI, S.; BOMBANA, A. C. Effect of endodontic procedures on enterococci, enteric bacteria and yeast in primary endodontic infections.

International Endodontic Journal, v. 38, p. 372-380, 2005.

GARCEZ, A. S.; NUÑEZ, S. C.; LAGE-MARQUES, J. L.; JORGE, A. O. C.; RIBEIRO, M. S. Efficiency of $\mathrm{NaOCl}$ and laser-assisted photosensitization on the reduction of Enterococcus faecalis in vitro. Oral Surgery Oral Medicine Oral Pathology Oral Radiology and Endodontology, v.102, p. 93-98, 2006.

GIOSO, M. A. Odontologia para o clínico de pequenos animais, 2.ed. São Paulo: Manole, 2007. 160 p.

GUTKNECHT, N.; MORITZ, A.; CONRADS, G.; SIEVERT, T.; LAMPERT, F. Bactericidal effect of the Nd:YAG laser in vitro root canals. Journal of Clinical Medicine and Surgery, v. 14, p. 77-80, 1996.

HAYEK, R. R. A.; ARAUJO, N. S.; GIOSO, M. A.; FERREIRA, J.; BAPTISTASOBRINHO, C. A.; YAMADA J. R, A. M.; RIBEIRO, M. S. Comparative study between the effects of photodynamic therapy and conventional therapy on microbial reduction in ligature-induced peri-iimplantitis in dogs. Journal of Periodontology, $v$. 76 , p. 1275-1281, 2005. 
ITO, T. The dependence of photosensitizing efficacy of acridine orange and toluidine blue on the degree of sensitizer-cell interaction. Photochemistry and Photobiology, v. 31 , p. $565-570,1980$.

KAWAMOTO, K.; SEND, N.; SHIMADA, K.; ITO, K.; HIRANO, Y.; MURAI, S. Antibacterial effect of yellow He-Ne laser irradiation with crystal violet solution on Porphyromons gingivalis: an evaluation using experimental rat model involving subcutaeous abcess. Lasers in Medical Science, v. 15, p. 257-262, 2000.

KÖNIG, K.; TESCHKE, M.; SIGUSCH, B.; GLOCKMANN, E.; EICK, S.; PFISTER, W. Red light kills bacteria via photodynamic action. Cellular and Molecular Biology, v. 47, p. $1297-303,2000$

LE GOFF, A.; BUNETEL, L.; MOUTON, C.; BONNAURE-MALLET, M. Evaluation of root canal bacteria and their antimicrobial susceptibility in teeth with necrotic pulp. Oral Microbiology and Immunology, v. 12, p. 318-322, 1997.

LEON-ROMAN, M. A.; GIOSO, M. A. Tratamento de Canal Convencional: opção à extração de dentes afetados endodonticamente. Revista Clínica Veterinária, v.7, n. 40, p. 32-44, 2002.

MALIK, Z.; HANANIA, J.; NITZAN, Y. Bactericidal effects of photoactivated porphyrins - an alternative approach to antimicrobial drugs. Photochemistry and Photobiology, v. 5, p. 281-293, 1990.

MARAIS, J. T.; WILLIAMS, W. P. Antimicrobial effectiveness of electro-chemically activated water as an endodontic irrigation solution. International Endodontic Journal, v. 34, p. 237-243, 2001

MCKINLEY, I. B.; LUDLOW, M. O. Hazards of laser smoke during endodontic therapy. Journal of Endodontics, v. 20, p. 558-559, 1994 
MENEZES, M. M.; VALERA, M. C.; JORGE, A. O. C.; KOGA-ITO, C. Y.; CAMARGO, C. H. R.; MANCINI, M. N. G. In vitro evaluation of the effectiveness of irrigants and intracanal medicaments on microorganisms within root canals. International Endodontic Journal, v. 37, p. 311-319, 2004

MÖLLER, A. J. R. Microbiological examination of root canals and periapical tissues of human teeth. Thesis, Odontologisk Tidskrift. v. 74, p. 1-38, 1966.

MÜLLER, S.; HEINRICH, W.; DOBLER-GIRDZIUNAITE, D.; FIEDLER, D.; HALLER, $U$. Enhanced photodynamic effects using fractionated laser light. Journal of Photochemistry and Photobiology, v. 42, p. 67-70, 1998.

NIKOLAOS, S.; CHEN, P. S.-Y.; MORRIS, J. T.; RUGGIERO, K.; ABERNETHY, A. D.; SOM, S.; FOSCHI, F.; DOUCETTE, S.; BAMMANN, L. L.; FONTANA, C. R.; DOUKAS, A. G.; STASHENKO, P. P. Photodynamic therapy for endodontic disinfection. Journal of Endodontics, v. 32, p. 979-984, 2006.

OKAMOTO, H.; IWASE, T.; MORIOKA, T. Dye-medicated bacterial effect of He-Ne laser irradiation on oral microorganisms. Laser in Surgery and Medicine, v. 12, p. 450-458, 1992.

ÖNÇAĞ, Ö.; HOŞGÖR, M.; HILMIOĞLU, S.; ZEKIOĞLU, O.; ERONAT, C.; BURHANOĞLU, D. Comparison of antibacterial and toxic effects of various root canal irrigants. International Endodontic Journal, v. 36, p. 423-432, 2003.

PAIVA, J. G.; ANTONIAZZI, J. H. O uso de uma associação de peróxido de uréia e detergente (Tween 80) no preparo químico-mecânico dos canais radiculares. Rev. Associação Paulista de Cirurgiões-Dentistas, v. 27, p. 416-422, 1973.

PAARDEKOOPER, M.; DE BRUIJNE, A.; VAN STEVENICK, J.; VAN DER BROEK, P. J. Intracellular damage in cells caused by photodynamic treatment with toluidine blue. Photochemistry and Photobiology, v. 61, p. 84-89, 1995. 
PERVAIZ, S.; OLIVO, M. Art and science of photodynamic therapy. Clinical and Experimental Pharmacology and Physiology, v. 33, p. 551-556, 2006.

PETERS, L. B.; WESSELINK, P. R. Periapical healing of endodontically treated teeth in one and two visits obturated in the presence or absence of detectable microorganisms. International Endodontic Journal, v. 35, p. 660-667, 2002.

PETERS, L. B.; WESSELINK, P. R.; VAN WINKELHOFF, A. J. Combinations of bacterial species in endodontic infection. International Endodontic Journal, v. 35, p. 698-702, 2002.

PINHEIRO, E. T.; GOMES, B. P. F. A.; FERRAZ, C. C. R.; SOUSA, E. L. R.; TEIXEIRA, F. B.; SOUZA-FILHO, F. J. Microorganisms from canals of root-filled teeth with periapical lesions. International Endodontics Journal, v. 36, p. 1-11, 2003

QIN, Y. L.; LUAN, X. L.; BI, L. J.; SHENG, Y. Q.; ZHOU, C. N.; ZHANG, Z. G. Comparison of toluidine blue-mediated photodynamic therapy and conventional scaling treatment for periodontitis in rats. Journal of Periodontal Research, v. 43, p. 162-167, 2008

RADCLIFFE, C. E.; POTOURIDOU, L.; QURESHI, R.; HABAHBEH, N.; QUALTROUGH, A.; WORTHINGTON, H.; DRUCKER, D. B. Antimicrobial activity of varying concentrations of sodium hypochlorite on the endodontic microorganisms Actinomyces israelii, A.naes/undii, Candida albicans and Enterococcus faecalis. International Endodontic Journal, v. 37, p. 438-446, 2004.

SEAL, G. J.; NG, Y.-L.; SPRATT, D.; BHATTI, M.; GULABIVALA, K. An in vitro comparison of the bactericidal efficacy of lethal photosensitization or sodium hyphochlorite irrigation on Streptococcus intermedius biofilms in root canals. International Endodontic Journal, v. 35, p. 268-274, 2002.

SIQUEIRA JR., J. F. Aetiology of root canal treatment failure: why well treated teeth can fail. International Endodontic Journal, v. 34, p. 1-10, 2001. 
SIQUERIA JR., J. F.; UZEDA, M. Disinfection by calcium hydroxide paste of dentinal tubules infected with two obligate and one facultative anaerobic bacteria. Journal of Endodontics, v. 22, p. 674-676, 1996a.

SIQUERIA JR., J. F.; UZEDA, M.; FONSECA, M. E. F. A scanning electron microscopic evaluation of in vitro dentinal tubules penetration by selected anaerobic bacteria. Journal of Endodontics, v. 22, p. 308-310, 1996b.

SPANO, J. C. E. Estudo "in vitro" das propriedades físico-químicas das soluções de hipoclorito de sódio, em diferentes concentrações, antes e após a dissolução de tecido pulpar bovino. 1999. 96 p., Dissertação (Mestrado) Faculdade de Odontologia de Ribeirão Preto, Universidade de São Paulo, Ribeirão Preto, 1999.

SUNDQVIST, G. Association between microbial species in dental root canal infections. Oral Microbiology and Immunology, v. 7, p. 257-262, 1992b.

SUNDQVIST, G. Ecology of the root canal flora. Journal of Endodontics, v. 18, p. 427-430, 1992a.

SUNDQVIST, G. Bacteriological studies of necrotic dental pulps. 1976. 94 p. (Mestrado) - University of Umeo, Suécia, 1976.

SUNDQVIST, G.; FIGDOR, D.; PERSSON, S.; SJOGREN, U. Microbiologic analysis of teeh with failed endodontic treatment and the outcome of conservative retreatment. Oral Surgery Oral Medicine Oral Pathology Oral Radiology and Endodontology, v. 85, p. 86-93, 1998

TOMASELLI, F.; MAIER, A.; SANKIN, O.; ANEGG, U.; STRANZL, U.; PINTER, H.; KAPP, K.; SMOLLE-JUTTNER, F. M. Acute effects of combined photodynamic therapy and hyperbaric oxygenation in lung cancer - A clinical pilot study. Laser in Surgery and Medicine, v. 28, p. 399-403, 2001. 
UTSONOMIYA, T. A histopathological study of the effects of low-power laser irradiation on wound healing of exposed dental pulp tissues in dogs, with special reference to lectins and collagens. Journal of Endodontics , v. 24 , p. 187-193, 1998.

VENCESLAU, A.; GIOSO, M. A. Prevalência de fraturas dentárias e exposição pulpar associada ao tipo de dieta em cães e gatos. São Paulo, 2000. p. 1-10. Vencedores do prêmio Waltham 2000.

WAINWRIGHT, M. Photodynamic antimicrobial chemotherapy (PACT). Journal of Antimicrobial Chemotherapy, v. 42, p. 13-28, 1998.

WETTER, N. U. Princípios e física do laser. In: MAIO, M.; Tratado de Medicina estética. 1 ed. São Paulo: Ed.Rocca, 2004. v.2.

WILSON, M.; DOBSON, J.; SAKAR, S. Sensitization of periodontopathogenic bacteria to killing by light from a low power laser. Oral Microbiology Immunology, v. 8, p. 182-187, 1993. 
APÊNDICE 


\section{APÊNDICE}

APÊNDICE A: Contagem de Unidades Formadoras de Colônia (UFC) segundo a diluição e meio de cultivo, para cada dente estudado no Grupo I, após acesso ao canal radicular, após o preparo químico-cirúrgico e após a terapia fotodinâmica

\begin{tabular}{|c|c|c|c|c|c|c|c|c|c|c|}
\hline \multirow[t]{2}{*}{ DENTE } & \multirow[t]{2}{*}{ DILUIÇÃO } & \multicolumn{3}{|c|}{$\begin{array}{c}1^{\mathrm{a}} \text { COLETA } \\
\text { acesso ao canal } \\
\text { (UFC) }\end{array}$} & \multicolumn{3}{|c|}{$\begin{array}{l}2^{\mathrm{a}} \text { COLETA } \\
\text { após PQC } \\
\text { (UFC) }\end{array}$} & \multicolumn{3}{|c|}{$\begin{array}{l}3^{\mathrm{a}} \text { COLETA } \\
\text { após PDT } \\
\text { (UFC) }\end{array}$} \\
\hline & & BRU & m-Ent & Sab & BRU & m-Ent & Sab & BRU & m-Ent & Sab \\
\hline \multirow{4}{*}{01} & sd & 325 & 245 & $\overline{0}$ & 0 & 0 & $\overline{0}$ & 0 & 0 & 0 \\
\hline & $1 / 10$ & 174 & 193 & 0 & 0 & 0 & 0 & 0 & 0 & 0 \\
\hline & $1 / 100$ & 0 & 35 & 0 & 0 & 0 & 0 & 0 & 0 & 0 \\
\hline & $1 / 1000$ & 0 & 0 & 0 & 0 & 0 & 0 & 0 & 0 & 0 \\
\hline \multirow{4}{*}{02} & sd & 170 & 305 & 30 & 0 & 0 & 0 & 0 & 0 & 0 \\
\hline & $1 / 10$ & 120 & 80 & 18 & 0 & 0 & 0 & 0 & 0 & 0 \\
\hline & $1 / 100$ & 63 & 17 & 4 & 0 & 0 & 0 & 0 & 0 & 0 \\
\hline & $1 / 1000$ & 5 & 0 & 0 & 0 & 0 & 0 & 0 & 0 & 0 \\
\hline \multirow{4}{*}{03} & sd & 0 & 0 & 0 & 3 & 0 & 0 & 0 & 0 & 0 \\
\hline & $1 / 10$ & 2 & 0 & 0 & 0 & 0 & 0 & 0 & 0 & 0 \\
\hline & $1 / 100$ & 60 & 0 & 0 & 0 & 0 & 0 & 0 & 0 & 0 \\
\hline & $1 / 1000$ & 50 & 0 & 0 & 0 & 0 & 0 & 0 & 0 & 0 \\
\hline \multirow{4}{*}{04} & sd & 176 & 0 & 0 & 0 & 0 & 0 & 0 & 0 & 0 \\
\hline & $1 / 10$ & 90 & 0 & 0 & 0 & 0 & 0 & 0 & 0 & 0 \\
\hline & $1 / 100$ & 34 & 0 & 0 & 0 & 0 & 0 & 0 & 0 & 0 \\
\hline & $1 / 1000$ & 0 & 0 & 0 & 0 & 0 & 0 & 0 & 0 & 0 \\
\hline \multirow{4}{*}{05} & sd & 310 & 112 & 170 & 0 & 0 & 0 & 0 & 0 & 0 \\
\hline & $1 / 10$ & 140 & 48 & 97 & 0 & 0 & 0 & 0 & 0 & 0 \\
\hline & $1 / 100$ & 98 & 0 & 20 & 0 & 0 & 0 & 0 & 0 & 0 \\
\hline & $1 / 1000$ & 32 & 0 & 0 & 0 & 0 & 0 & 0 & 0 & 0 \\
\hline
\end{tabular}




\begin{tabular}{|c|c|c|c|c|c|c|c|c|c|c|}
\hline \multirow[t]{2}{*}{ DENTE } & \multirow[t]{2}{*}{ DILUIÇÃO } & \multicolumn{3}{|c|}{$\begin{array}{c}1^{\mathrm{a}} \text { COLETA } \\
\text { acesso ao canal } \\
\text { (UFC) }\end{array}$} & \multicolumn{3}{|c|}{$\begin{array}{c}2^{\mathrm{a}} \text { COLETA } \\
\text { após PQC } \\
\text { (UFC) }\end{array}$} & \multicolumn{3}{|c|}{$\begin{array}{c}3^{\text {a }} \text { COLETA } \\
\text { após PDT } \\
\text { (UFC) }\end{array}$} \\
\hline & & BRU & m-Ent & Sab & BRU & m-Ent & Sab & BRU & m-Ent & Sab \\
\hline \multirow{4}{*}{06} & $\mathrm{sd}$ & 231 & 192 & 42 & 45 & 0 & 0 & 3 & 0 & 0 \\
\hline & $1 / 10$ & 67 & 90 & 7 & 5 & 0 & 0 & 1 & 0 & 0 \\
\hline & $1 / 100$ & 20 & 23 & 0 & 2 & 0 & 0 & 0 & 0 & 0 \\
\hline & $1 / 1000$ & 12 & 0 & 0 & 1 & 0 & 0 & 0 & 0 & 0 \\
\hline \multirow{4}{*}{07} & sd & 0 & 0 & 0 & 0 & 0 & 0 & 0 & 0 & 0 \\
\hline & $1 / 10$ & 0 & 0 & 0 & 0 & 0 & 0 & 0 & 0 & 0 \\
\hline & $1 / 100$ & 0 & 0 & 0 & 0 & 0 & 0 & 0 & 0 & 0 \\
\hline & $1 / 1000$ & 0 & 0 & 0 & 0 & 0 & 0 & 0 & 0 & 0 \\
\hline \multirow{4}{*}{08} & $s d$ & 198 & 37 & 0 & 0 & 0 & 0 & 0 & 0 & 0 \\
\hline & $1 / 10$ & 71 & 2 & 0 & 0 & 0 & 0 & 0 & 0 & 0 \\
\hline & $1 / 100$ & 1 & 0 & 0 & 0 & 0 & 0 & 0 & 0 & 0 \\
\hline & $1 / 1000$ & 0 & 0 & 0 & 0 & 0 & 0 & 0 & 0 & 0 \\
\hline \multirow{4}{*}{09} & sd & 332 & 219 & 0 & 0 & 1 & 0 & 0 & 0 & 0 \\
\hline & $1 / 10$ & 42 & 172 & 0 & 0 & 0 & 0 & 0 & 0 & 0 \\
\hline & $1 / 100$ & 1 & 13 & 0 & 0 & 0 & 0 & 0 & 0 & 0 \\
\hline & $1 / 1000$ & 0 & 0 & 0 & 0 & 0 & 0 & 0 & 0 & 0 \\
\hline \multirow{4}{*}{10} & $s d$ & 109 & 63 & 0 & 1 & 1 & 0 & 0 & 0 & 0 \\
\hline & $1 / 10$ & 15 & 14 & 0 & 0 & 0 & 0 & 0 & 0 & 0 \\
\hline & $1 / 100$ & 0 & 1 & 0 & 0 & 0 & 0 & 0 & 0 & 0 \\
\hline & $1 / 1000$ & 0 & 0 & 0 & 0 & 0 & 0 & 0 & 0 & 0 \\
\hline
\end{tabular}


APÊNDICE B. Contagem de Unidades Formadoras de Colônia (UFC) segundo a diluição e meio de cultivo, para cada dente estudado no Grupo II, após acesso ao canal radicular, após a terapia fotodinâmica e após o preparo químico-cirurgico

\begin{tabular}{|c|c|c|c|c|c|c|c|c|c|c|}
\hline \multirow[t]{2}{*}{ DENTE } & \multirow[t]{2}{*}{ DILUIÇÃO } & \multicolumn{3}{|c|}{$\begin{array}{c}1^{\text {a }} \text { COLETA } \\
\text { acesso ao canal } \\
\text { (UFC) }\end{array}$} & \multicolumn{3}{|c|}{$\begin{array}{l}2^{\mathrm{a}} \text { COLETA } \\
\text { após PDT } \\
\text { (UFC) }\end{array}$} & \multicolumn{3}{|c|}{$\begin{array}{l}3^{\mathrm{a}} \text { COLETA } \\
\text { após PQC } \\
\text { (UFC) }\end{array}$} \\
\hline & & BRU & m-Ent & Sab & BRU & m-Ent & Sab & BRU & m-Ent & Sab \\
\hline \multirow{4}{*}{11} & $\mathrm{sd}$ & 217 & 179 & 38 & 0 & 0 & 0 & 0 & 0 & 0 \\
\hline & $1 / 10$ & 182 & 87 & 5 & 0 & 0 & 0 & 0 & 0 & 0 \\
\hline & $1 / 100$ & 75 & 18 & 0 & 0 & 0 & 0 & 0 & 0 & 0 \\
\hline & $1 / 1000$ & 29 & 0 & 0 & 0 & 0 & 0 & 0 & 0 & 0 \\
\hline \multirow{4}{*}{12} & sd & 198 & 259 & 47 & 0 & 0 & 0 & 0 & 0 & 0 \\
\hline & $1 / 10$ & 125 & 115 & 23 & 0 & 0 & 0 & 0 & 0 & 0 \\
\hline & $1 / 100$ & 67 & 27 & 5 & 0 & 0 & 0 & 0 & 0 & 0 \\
\hline & $1 / 1000$ & 19 & 0 & 0 & 0 & 0 & 0 & 0 & 0 & 0 \\
\hline \multirow{4}{*}{13} & sd & 89 & 352 & 0 & 0 & 0 & 0 & 0 & 0 & 0 \\
\hline & $1 / 10$ & 28 & 174 & 0 & 0 & 0 & 0 & 0 & 0 & 0 \\
\hline & $1 / 100$ & 5 & 37 & 0 & 0 & 0 & 0 & 0 & 0 & 0 \\
\hline & $1 / 1000$ & 0 & 0 & 0 & 0 & 0 & 0 & 0 & 0 & 0 \\
\hline \multirow{4}{*}{14} & sd & 70 & 170 & 32 & 0 & 0 & 0 & 0 & 0 & 0 \\
\hline & $1 / 10$ & 32 & 50 & 10 & 0 & 0 & 0 & 0 & 0 & 0 \\
\hline & $1 / 100$ & 5 & 9 & 0 & 0 & 0 & 0 & 0 & 0 & 0 \\
\hline & $1 / 1000$ & 0 & 0 & 0 & 0 & 0 & 0 & 0 & 0 & 0 \\
\hline \multirow{4}{*}{15} & sd & 202 & 167 & 0 & 3 & 0 & 0 & 0 & 0 & 0 \\
\hline & $1 / 10$ & 45 & 57 & 0 & 0 & 0 & 0 & 0 & 0 & 0 \\
\hline & $1 / 100$ & 7 & 7 & 0 & 0 & 0 & 0 & 0 & 0 & 0 \\
\hline & $1 / 1000$ & 0 & 0 & 0 & 0 & 0 & 0 & 0 & 0 & 0 \\
\hline
\end{tabular}




\begin{tabular}{|c|c|c|c|c|c|c|c|c|c|c|}
\hline \multirow[t]{2}{*}{ DENTE } & \multirow[t]{2}{*}{ DILUIÇÃO } & \multicolumn{3}{|c|}{$\begin{array}{c}1^{\mathrm{a}} \text { COLETA } \\
\text { acesso ao canal } \\
\text { (UFC) }\end{array}$} & \multicolumn{3}{|c|}{$\begin{array}{l}2^{\text {a }} \text { COLETA } \\
\text { após PDT } \\
\text { (UFC) }\end{array}$} & \multicolumn{3}{|c|}{$\begin{array}{l}3^{\mathrm{a}} \text { COLETA } \\
\text { após PQC } \\
\text { (UFC) }\end{array}$} \\
\hline & & BRU & m-Ent & Sab & BRU & m-Ent & Sab & BRU & m-Ent & Sab \\
\hline \multirow{4}{*}{16} & $\mathrm{sd}$ & 139 & 189 & 0 & 0 & 0 & 0 & 0 & 0 & 0 \\
\hline & $1 / 10$ & 37 & 35 & 0 & 0 & 0 & 0 & 0 & 0 & 0 \\
\hline & $1 / 100$ & 0 & 2 & 0 & 0 & 0 & 0 & 0 & 0 & 0 \\
\hline & $1 / 1000$ & 0 & 0 & 0 & 0 & 0 & 0 & 0 & 0 & 0 \\
\hline \multirow{4}{*}{17} & sd & 64 & 296 & 0 & 0 & 0 & 0 & 0 & 0 & 0 \\
\hline & $1 / 10$ & 12 & 132 & 0 & 0 & 0 & 0 & 0 & 0 & 0 \\
\hline & $1 / 100$ & 3 & 3 & 0 & 0 & 0 & 0 & 0 & 0 & 0 \\
\hline & $1 / 1000$ & 0 & 0 & 0 & 0 & 0 & 0 & 0 & 0 & 0 \\
\hline \multirow{4}{*}{18} & sd & 202 & 159 & 12 & 0 & 0 & 0 & 0 & 0 & 0 \\
\hline & $1 / 10$ & 134 & 21 & 1 & 0 & 0 & 0 & 0 & 0 & 0 \\
\hline & $1 / 100$ & 3 & 0 & 0 & 0 & 0 & 0 & 0 & 0 & 0 \\
\hline & $1 / 1000$ & 0 & 0 & 0 & 0 & 0 & 0 & 0 & 0 & 0 \\
\hline \multirow{4}{*}{19} & sd & 203 & 246 & 0 & 0 & 0 & 0 & 0 & 0 & 0 \\
\hline & $1 / 10$ & 124 & 91 & 0 & 0 & 0 & 0 & 0 & 0 & 0 \\
\hline & $1 / 100$ & 3 & 12 & 0 & 0 & 0 & 0 & 0 & 0 & 0 \\
\hline & $1 / 1000$ & 0 & 0 & 0 & 0 & 0 & 0 & 0 & 0 & 0 \\
\hline \multirow{4}{*}{20} & sd & 93 & 103 & 0 & 0 & 0 & 0 & 0 & 0 & 0 \\
\hline & $1 / 10$ & 11 & 17 & 0 & 0 & 0 & 0 & 0 & 0 & 0 \\
\hline & $1 / 100$ & 0 & 2 & 0 & 0 & 0 & 0 & 0 & 0 & 0 \\
\hline & $1 / 1000$ & 0 & 0 & 0 & 0 & 0 & 0 & 0 & 0 & 0 \\
\hline
\end{tabular}


APÊNDICE C: Dados dos dez animais utilizados no estudo, pertencentes ao Grupo I

\begin{tabular}{lllll}
\hline Cães & Raça & Sexo & Idade & $\begin{array}{l}\text { Dentes } \\
\text { tratados* }\end{array}$ \\
\hline 01 & Pit Bull & Macho & 5 anos & 304 \\
02 & Pincher & Macho & 7 anos & 201 \\
03 & Shitzu & Fêmea & 3 anos & 104 \\
04 & Pit Bull & Fêmea & 5 anos & 204 \\
05 & Pastor Alemão & Macho & 4 anos & 204 \\
06 & SRD & Fêmea & 6 anos & 204 \\
07 & Pit Bull & Fêmea & 5 anos & 104 \\
08 & Pastor Belga & Macho & 4 anos & 104 \\
09 & SRD & Macho & 4 anos & 403 \\
10 & Cocker Spaniel & Fêmea & 10 anos & 304 \\
\hline
\end{tabular}

* Dentes identificados por numeração seguindo classificação de Triadan modificado 
APÊNDICE D: Dados dos dez animais utilizados no estudo, pertencentes ao Grupo II

\begin{tabular}{lllll}
\hline Cães & Raça & Sexo & Idade & $\begin{array}{l}\text { Dentes } \\
\text { tratados * }\end{array}$ \\
\hline 11 & Golden Retriever & Macho & 3 anos & 101 \\
12 & SRD & Fêmea & 6 anos & 404 \\
13 & SRD & Macho & 7 anos & 204 \\
14 & Pit Bull & Fêmea & 7 anos & 204 \\
15 & Pit Bull & Macho & 3 anos & 104 \\
16 & Dog de Bordeaux & Fêmea & 3 anos & 204 \\
17 & Pit Bull & Macho & 4 anos & 404 \\
18 & Pastor belga & Fêmea & 3 anos & 304 \\
19 & Labrador & Fêmea & 8 anos & 304 \\
20 & Fox Terrier & Fêmea & 11 anos & 404 \\
\hline * Dentes identificados por numeração seguindo classificação de Triadan modificado &
\end{tabular}

* Dentes identificados por numeração seguindo classificação de Triadan modificado 
88

Apêndice

LEON-ROMAN, M.A.

APÊNDICE E: Odontograma contendo numeração dos dentes, segundo classificação de Triadan modificado
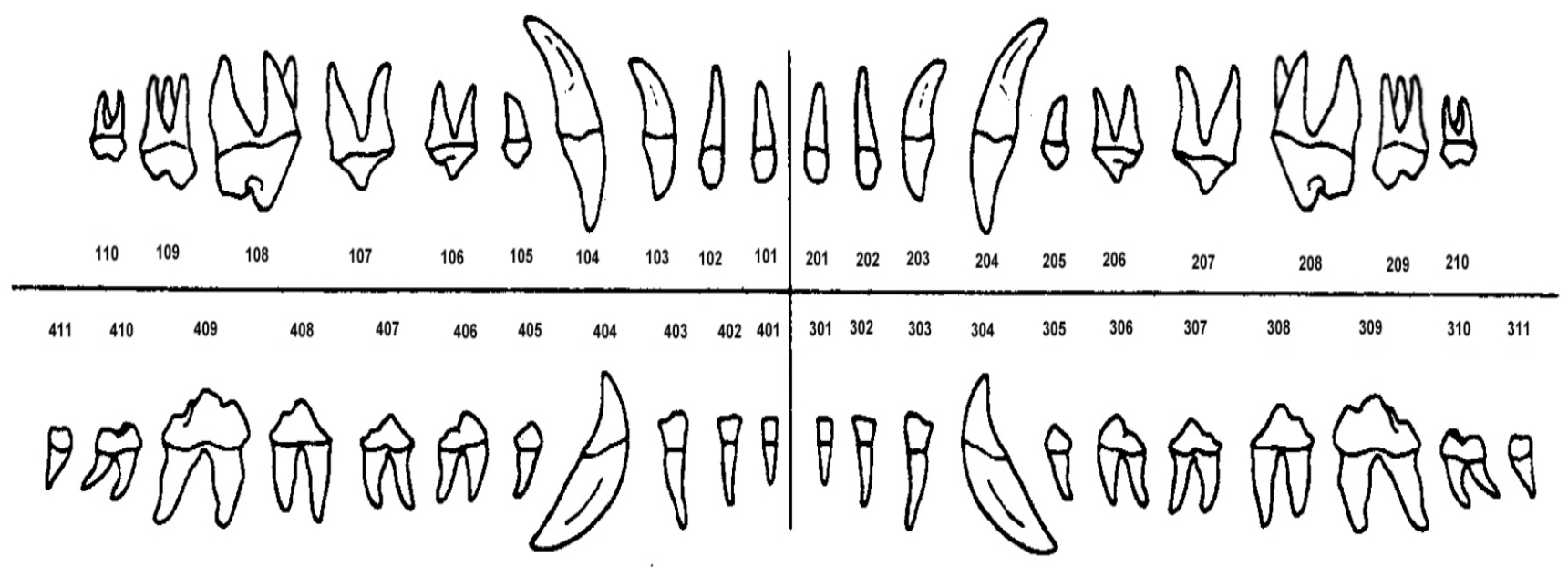

Fonte: LOC - FMVZ/USP 
APÊNDICE F: Lista de materiais utilizados

Líquido de Dakin - Hipoclorito de sódio 0,5\% - Reagentes Analíticos Dinâmica - São Paulo - SP - Brasil.

Endo-C-Prep - Peróxido de uréia (10\%), detergente tween80 (15\%) e carbowax (75\%) - Porto Alegre - RS - Brasil.

Endofill - Óxido de zinco e eugenol - Dentsply - Petrópolis - Rio de Janeiro - RJ Brasil.

Filme radiográfico intraoral - Kodak - São Paulo - SP - Brasil.

Limas endodônticas veterinárias tipo Hedström $60 \mathrm{~mm}$ - Henry Schein In. - Port Washington - NY - EUA.

Pontas de gutta-percha veterinárias - Dr.Shipp's Laboratories - EUA.

Pontas de papel absorvente veterinárias 60mm - Dr.Shipp's Laboratories - EUA.

Azuleno 25\% - 7-etil-1,4 dimetilazuleno - Biophitus Farmácia de Manipulação - São Paulo - SP - Brasil.

Periogard - gluconato de clorixidina a 0,12\% - Colgate-Palmolive - São Bernardo do Campo - SP.

Resina restauradora fotopolimerizável - bisfenol-A-glicildimetacrilato - 3M - Saint Paul - MN - EUA. 
Fotopolimerizador - modelo QHL 75 - Dentsply - São Paulo - SP - Brasil.

Turbina sub-sônica - Sonic Flex 2000N - Kavo - São Paulo - SP - Brasil.

Canetas de alta e baixa rotação - Kit acadêmico - Kavo - São Paulo - SP - Brasil.

Aparelho de RX - Modelo convencional de parede - São Paulo - SP - Brasil.

Equipo odontológico - Modelo Amadeus - Kavo - São Paulo - SP - Brasil. 